University of South Florida

DIGITAL COMMONS

Digital Commons @ University of

@ UNIVERSITY OF SOUTH FLORIDA

South Florida

$1-1-2009$

\title{
2009 Annual Report USF System
}

USF

Follow this and additional works at: https://digitalcommons.usf.edu/usf_accountability_reports

\section{Scholar Commons Citation}

USF, "2009 Annual Report USF System" (2009). USF Accountability Reports. 4.

https://digitalcommons.usf.edu/usf_accountability_reports/4

This Article is brought to you for free and open access by the USF Archives at Digital Commons @ University of South Florida. It has been accepted for inclusion in USF Accountability Reports by an authorized administrator of Digital Commons @ University of South Florida. For more information, please contact digitalcommons@usf.edu. 


\section{Florida Board of Governors State University System (SUS) Annual Report}

\section{University of South Florida System}

Approved by the USF Board of Trustees

December 16, 2009 


\section{$\underline{\text { Data Definitions }}$}

\section{GOAL 1:}

- Baccalaureate Degrees Awarded and Graduate Degrees Awarded: Graduate degrees include master's, research doctoral, and professional doctoral programs. Source: SUS Student Instruction File

\section{- \# and \% Baccalaureate Degrees Awarded (Non-Hispanic Blacks and Hispanics):} The number of baccalaureate degrees granted to non-Hispanic black students or Hispanic students. The percentage is the number of baccalaureate degrees awarded to each group divided by the total number of degrees awarded, excluding those awarded to non-resident aliens and those not reporting race/ethnicity. Source: SUS Student Instruction File

- \# and \% Baccalaureate Degrees Awarded (Pell Recipients): The number of baccalaureate degrees awarded to federal Pell grant recipients, an indicator of low family income. For this report, a Pell grant recipient is defined as a student who received Pell within six years of graduation. The percentage is the number of baccalaureate degrees awarded to Pell recipients as listed above divided by the total number of degrees awarded, excluding those awarded to non-resident aliens. Sources: SUS Student Instruction File and Student Financial Aid File

\section{GOAL 2:}

- \# Degrees Awarded in Select Areas of Strategic Emphasis: Degrees as reported above by six-digit Classification of Instruction Program. The areas of strategic emphasis were selected by the Board of Governors staff in consultation with business and industry groups.

- Pass Rates on Professional Licensure Examinations: Many professional licensure data, gathered by the respective licensing boards and housed within the Department of Business and Professional Regulation, are not currently formatted and do not contain sufficient information to match to SUS data. Board of Governors staff will work with individuals from the appropriate agencies to try to get data in the needed format.

\section{GOAL 3:}

- Federally Financed and Total Academic Research and Development Expenditures: The National Science Foundation conducts an annual survey of colleges and universities regarding research and development expenditures. These amounts combine reported science and engineering R\&D expenditures with reported nonscience and engineering expenditures. Dollars are in nominal dollars (i.e., not inflationadjusted). Source: http://webcaspar.nsf.gov/ 
- \# Licenses/Options Executed: Count of the number of licenses/options executed in the fiscal year for all technologies. Each license agreement is counted separately. Source: AUTM Licensing Survey

- Licensing Income Received: License issue fees, payments under options, annual minimums, running royalties, termination payments, amount of equity received when cashed-in, and software and biological material end-user license fees of $\$ 1,000$ or more, but not research funding, patent expense reimbursement, valuation of equity not cashed-in, software and biological material end-user license fees of less than $\$ 1,000$, or trademark licensing royalties from university insignia. Source: AUTM Licensing Survey

\section{$\underline{\text { RESOURCES, EFFICIENCIES, AND EFFECTIVENESS }}$}

- 6 -Year Graduation and Retention Rates (FTICs), 4-Year Graduation and Retention
Rates (AA Transfers), 5-Year Graduation and Retention Rates (Other Transfers): An FTIC cohort is defined as undergraduates entering in fall term or summer continuing to fall with fewer than 12 hours earned since high school graduation. An AA Transfer cohort is defined as undergraduates entering in fall term or summer continuing to fall and having earned an AA degree from an institution in the Florida College System. An Other Transfer cohort is defined as undergraduates entering in fall term or summer continuing to fall who are not FTICs or AA transfers. The rate is the percentage of the initial cohort that had either graduated from or was still enrolled in the sixth academic year for FTIC students, fourth year for AA Transfers, and fifth year for Other Transfers. Both full-time and part-time students are included in the calculation. Source: SUS Retention File

- Student-Faculty Ratio: The ratio of full-time equivalent students (full-time plus 1/3 part time) to full-time equivalent instructional faculty (full time plus $1 / 3$ part time). In the ratio calculations, exclude both faculty and students in stand-alone graduate or professional programs such as medicine, law, veterinary, dentistry, social work, business, or public health in which faculty teach virtually only graduate-level students. This metric does not count undergraduate or graduate student teaching assistants as faculty. Source: Common Data Set/IPEDS

- Funding per FTE Student: E\&G appropriation and tuition revenues are divided by total student FTE. Only state-fundable credit hours are used. To allow for national comparisons, FTE for this metric uses the standard IPEDS definition of FTE, equal to 30 credit hours for undergraduates and 24 for graduates. Sources: Operating Budget, SUS Student Instruction File 


\begin{tabular}{|c|c|c|c|c|c|c|c|}
\hline \multicolumn{8}{|c|}{ 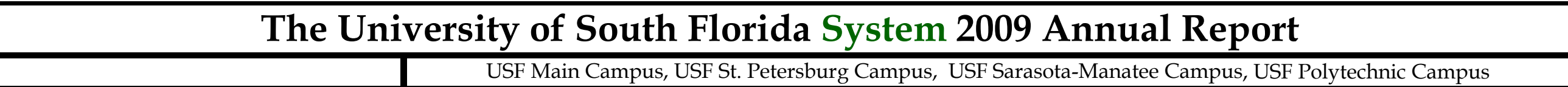 } \\
\hline Enrollments & $\#$ & $\%$ & \multicolumn{3}{|c|}{ Degree Programs Offered (2009) } & \multicolumn{2}{|r|}{ Carnegie Classification } \\
\hline $\begin{array}{c}\text { TOTAL } \\
\text { (Fall 2008) }\end{array}$ & 46,332 & -- & \multicolumn{2}{|l|}{ TOTAL } & 233 & $\begin{array}{l}\text { Undergraduate } \\
\text { Instructional Program: }\end{array}$ & $\begin{array}{l}\text { Balanced arts \& sciences/professions, high graduate } \\
\text { coexistence }\end{array}$ \\
\hline Black & 5,341 & $12 \%$ & \multicolumn{2}{|c|}{ Baccalaureate } & 91 & Graduate Instructional & Comprehensive doctoral with medical/veterinarv \\
\hline Hispanic & 5,829 & $13 \%$ & \multicolumn{2}{|c|}{ Master's \& Specialist's } & 100 & Program: & 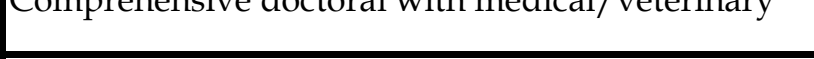 \\
\hline White & 30,206 & $65 \%$ & \multicolumn{2}{|c|}{ Research Doctorates } & 37 & Enrollment Profile: & High undergraduate \\
\hline Other & 4,956 & $11 \%$ & \multicolumn{2}{|c|}{ Professional Doctorates } & 4 & Undergraduate Profile: & $\begin{array}{l}\text { Medium full-time four-year, selective, higher } \\
\text { transfer-in }\end{array}$ \\
\hline Full-Time & 29,704 & $64 \%$ & \multirow{2}{*}{$\begin{array}{c}\text { Faculty } \\
\text { (Fall 2008) }\end{array}$} & \multirow{2}{*}{$\begin{array}{l}\text { Full- } \\
\text { Time }\end{array}$} & \multirow{2}{*}{$\begin{array}{l}\text { Part- } \\
\text { Time }\end{array}$} & Size and Setting: & Large four-year, primarily nonresidential \\
\hline Part-Time & 16,628 & $36 \%$ & & & & \multirow{2}{*}{ Basic: } & \multirow{2}{*}{ Research Universities (very high research activity) } \\
\hline Undergraduate & 35,120 & $76 \%$ & TOTAL & 1,582 & 234 & & \\
\hline Graduate & 9,149 & $20 \%$ & Tenure/T. Track & 1,103 & 80 & \multirow{2}{*}{ Elective Classification: } & Community Engagement: \\
\hline Unclassified & 2,063 & $4 \%$ & Non-Ten. Track & 479 & 154 & & Outreach \& Partnerships \\
\hline
\end{tabular}

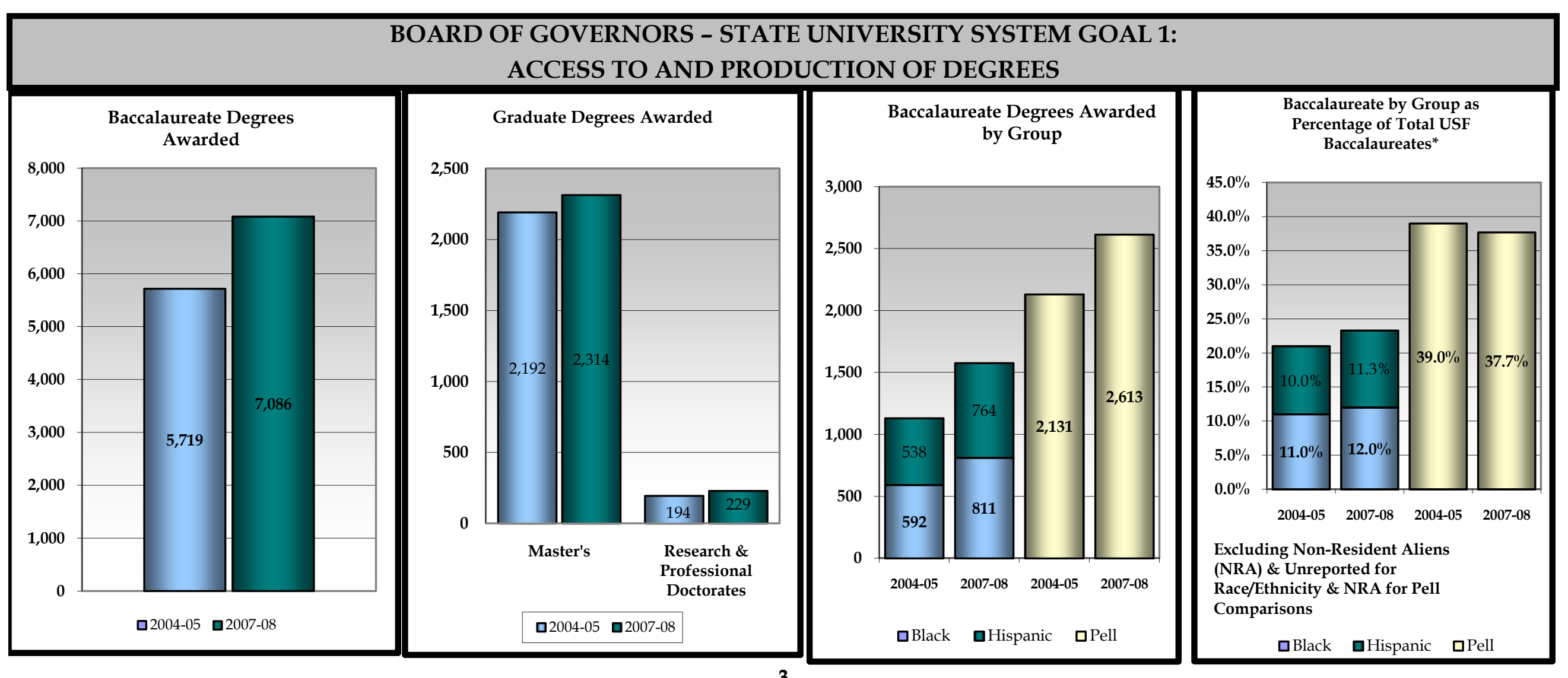




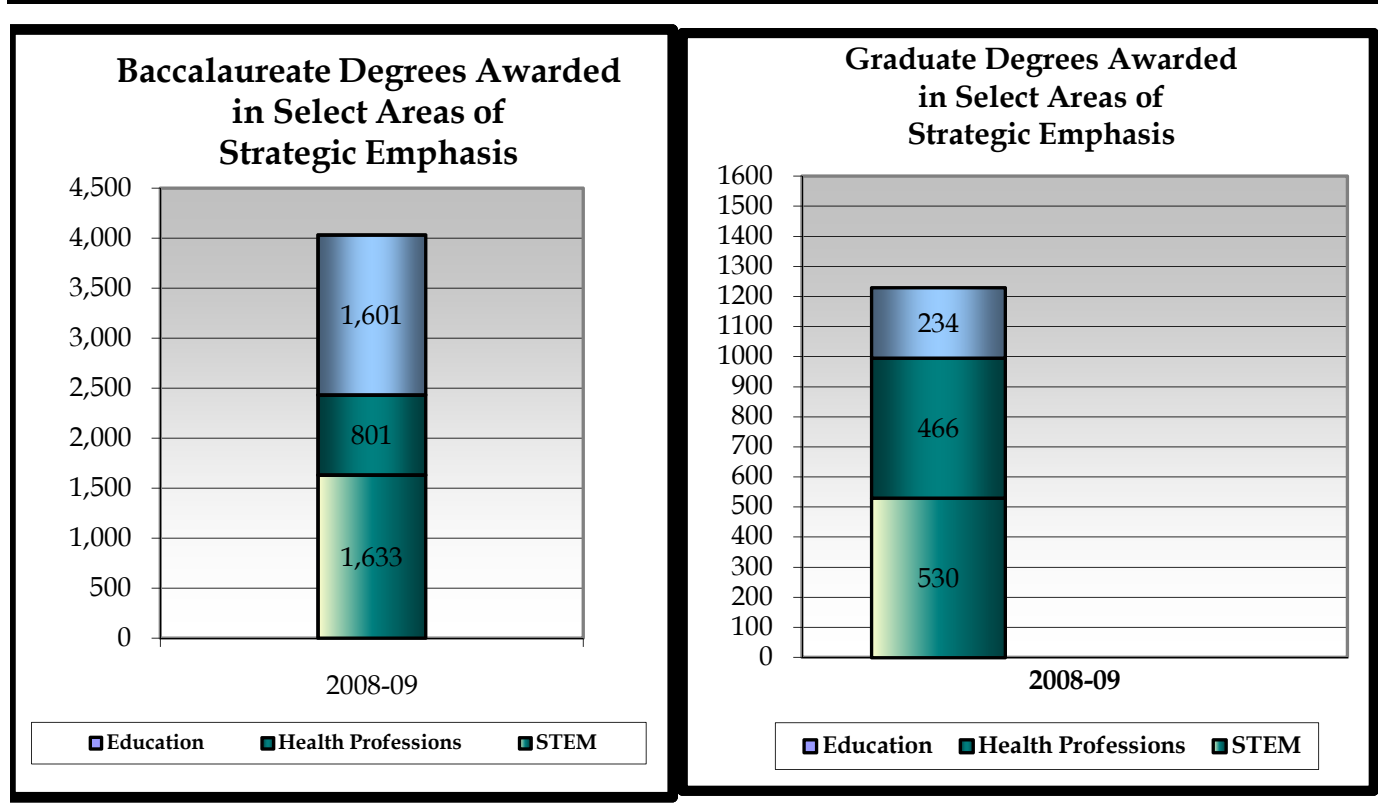

Example for Demonstration Only.
Pass Rates on Licensure Examinations

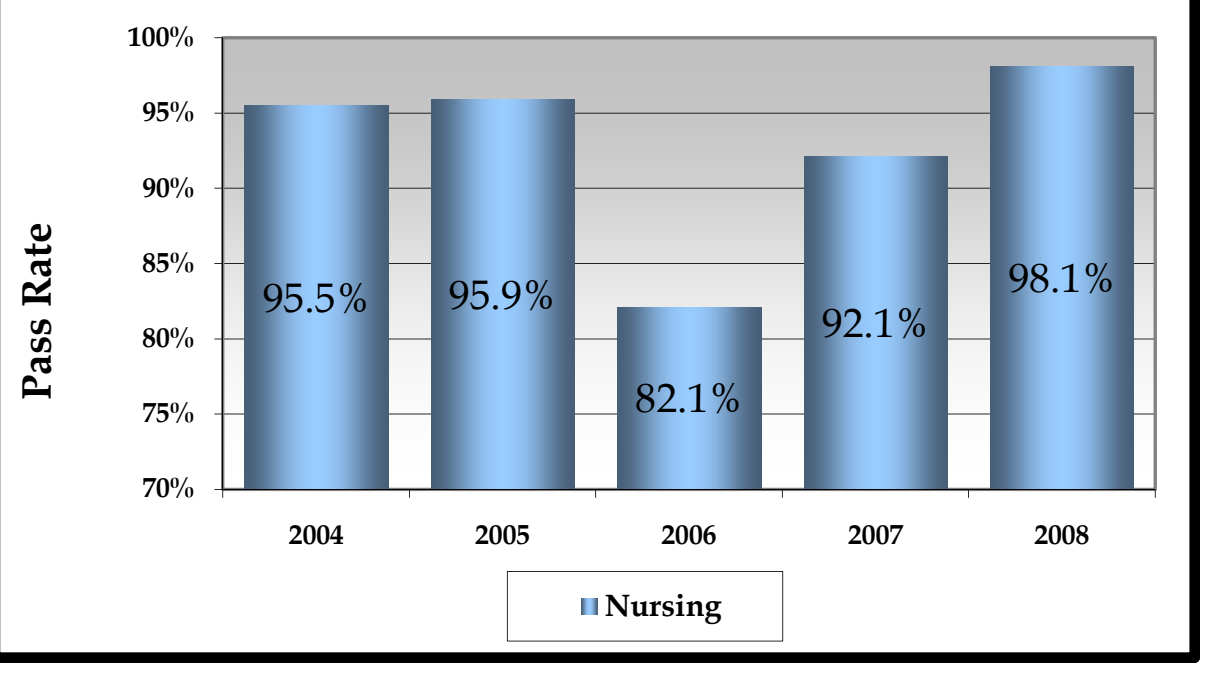

See ENDNOTES Regarding Pass Rates.

\section{BOARD OF GOVERNORS - STATE UNIVERSITY SYSTEM GOAL 3:}

BUILDING WORLD-CLASS ACADEMIC PROGRAMS AND RESEARCH CAPACITY
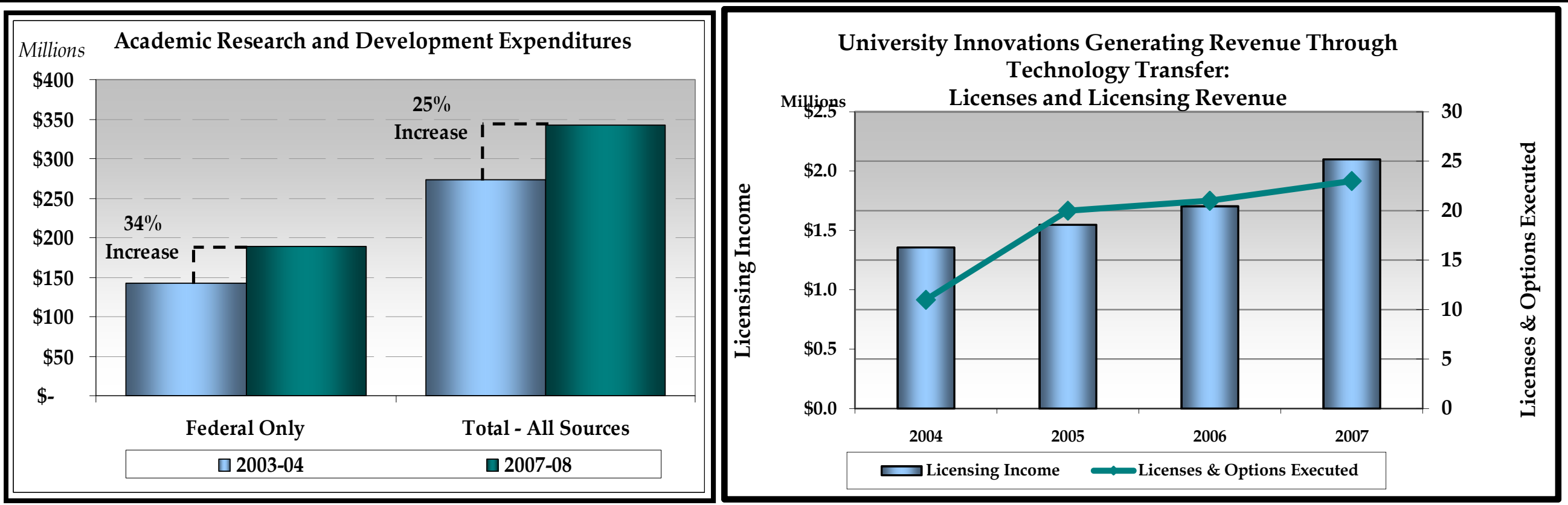

University Innovations Generating Revenue Through Technology Transfer: 
Key University Achievements [Include a maximum of three in each category.]

\section{Student awards/achievements}

(1) Several USF students have earned prestigious national and international awards. Graduate student honors include three Fulbright Fellows, one Fulbright-Hayes Fellow, and a Jacob K. Javits Fellow. Two undergraduate students earned Benjamin A. Gilman scholarships, and one other was honorable mention for the Barry M. Goldwater Scholarship and Excellence in Education Program.

\section{- Faculty awards/achievements}

(1) USF President Judy Genshaft has been named chair of the Board of Directors at the American Council on Education (ACE), the nation's largest association representing accredited colleges and universities.

(2) In the

Tampa Bay area, nearly one third of the physicians who made the 2008 Best Doctors in America list work at USF Health. And when you include the generous volunteer faculty members (those who teach medical students several times each year) and College of Medicine alumni in private practice locally, the numbers go up even more - 62 percent of the list has a connection with USF Health. The annual list for Best Doctors in America is compiled from surveys of physicians asking them who they would go to for treatment in their specialty. The result is a national listing of 30,000 physicians in more than 40 specialties.

\section{Program awards/achievements}

In 2008, the Florida Board of Governors granted USF approval to establish new doctoral programs in history, government, and sociology. The programs are linked, which is quite different from traditional, discipline-based programs. They focus on building sustainable healthy communities in a global context. USF was also granted approval to establish a doctorate program in pharmacy. The Pharm.D. degree will help the state meet the ever-increasing demand for pharmacists.

\section{- Research awards/achievements}

(1) With a $213 \%$ increase between 2000-20007, no other American university grew its federal research enterprise at a faster rate than USF, according to the Chronicle of Higher Education.

(2) In 2008-09, USF's funded research generated around \$360 million in external awards from federal, state, industry, foundation and other sponsors who are our partners in discovery and innovation that benefits Florida citizens, develops and commercializes products, knowhow and processes, and creates start-up companies and jobs. Such activities lead to economic development and create solutions to local, national and global problems.

(3) USF is launching on a bold new plan to fight diabetes on every front with its Center of Excellence for Diabetes and Autoimmune Disorders. Already a national leader in epidemiological research to understand and prevent diabetes, USF is working to dramatically increase its clinical research, expand its diabetes education program, and establish a comprehensive center that will offer patients a new level of care in Florida. USF hopes to build facilities to conduct research on possible cures for diabetes, in both outpatient and inpatient settings. USF's Pediatric Epidemiology Center has received more than $\$ 300$ million in federal grant funding to direct global efforts in juvenile diabetes research. 


\section{- Institutional awards/achievements}

(1) The Corporation for National and Community Service honored the University of South Florida with a place on the President's Higher Education Community Service Honor Roll for exemplary service efforts and service to America's communities. (2) USF purchased the R/V WeatherBird II, a 115-foot, 194-ton research vessel equipped for a new era of scientific teaching and research. The R/V WeatherBird II was purchased by USF for $\$ 2.1$ million for use through the Florida Institute of

Oceanography, a consortium of Florida's public universities, private higher education institutions and state agencies involved in marine research.

BOARD OF GOVERNORS - STATE UNIVERSITY SYSTEM GOAL 4: MEETING COMMUNITY NEEDS AND FULFILLING UNIQUE INSTITUTIONAL RESPONSIBILITIES 


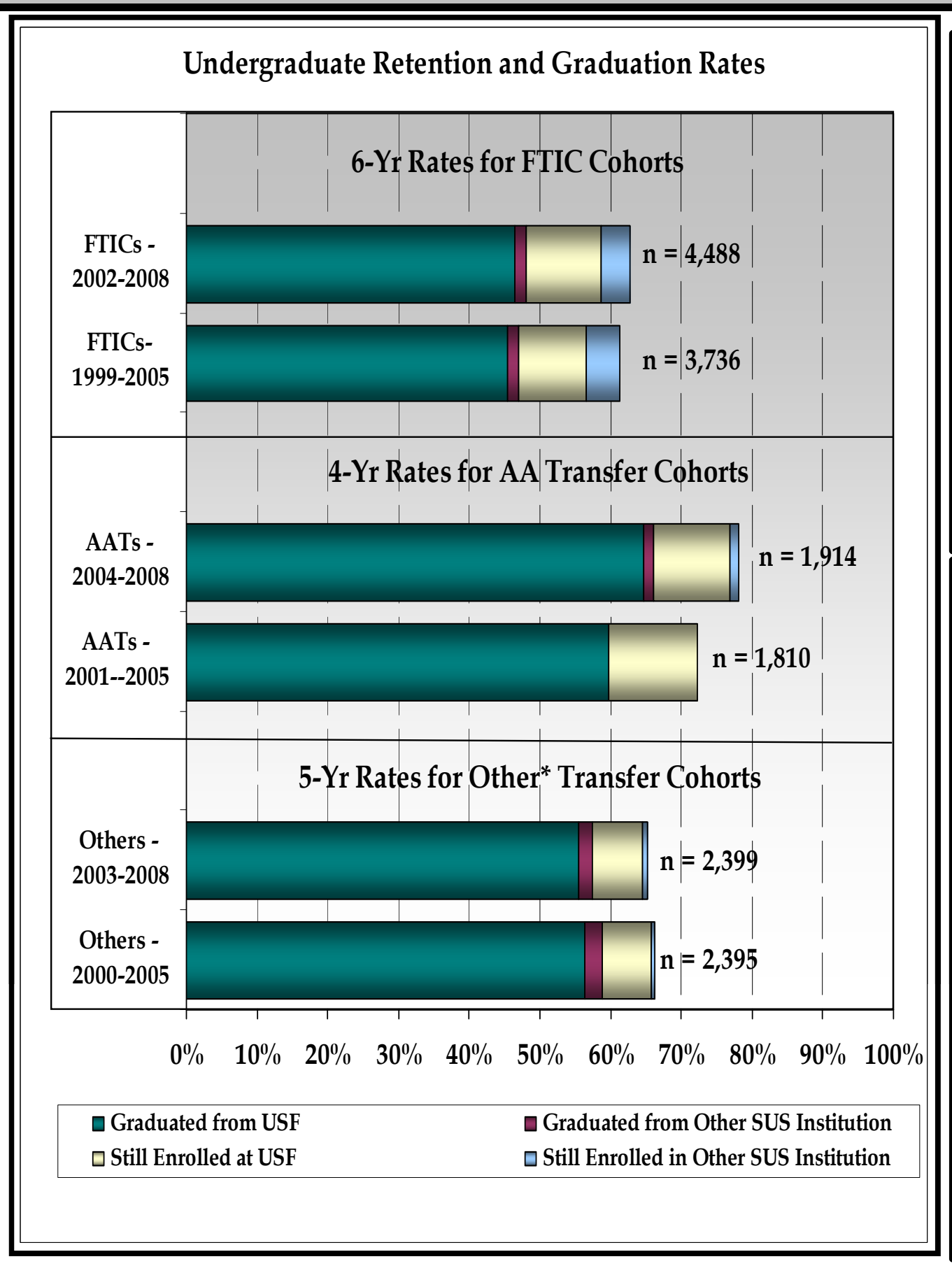

* The composition of "Other Transfer" cohorts may vary greatly by institution.

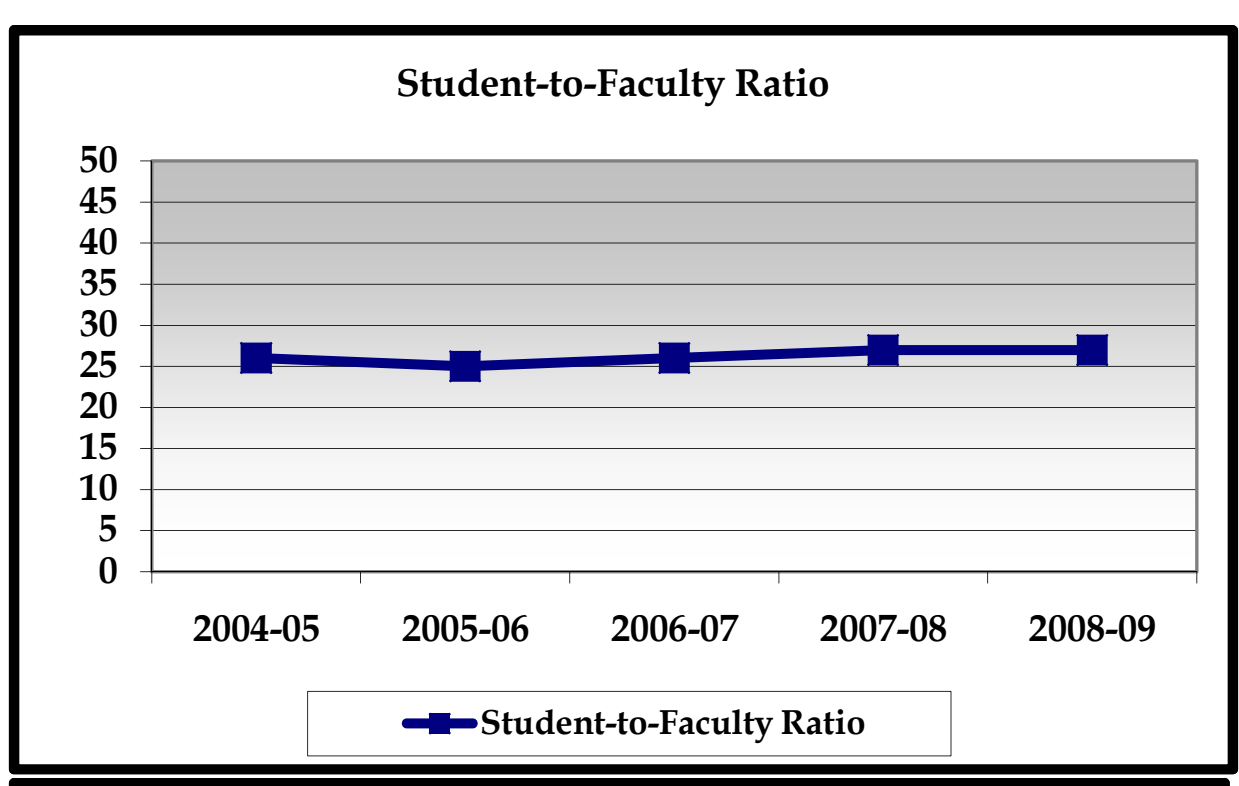

\section{Funding Per Student FTE**}

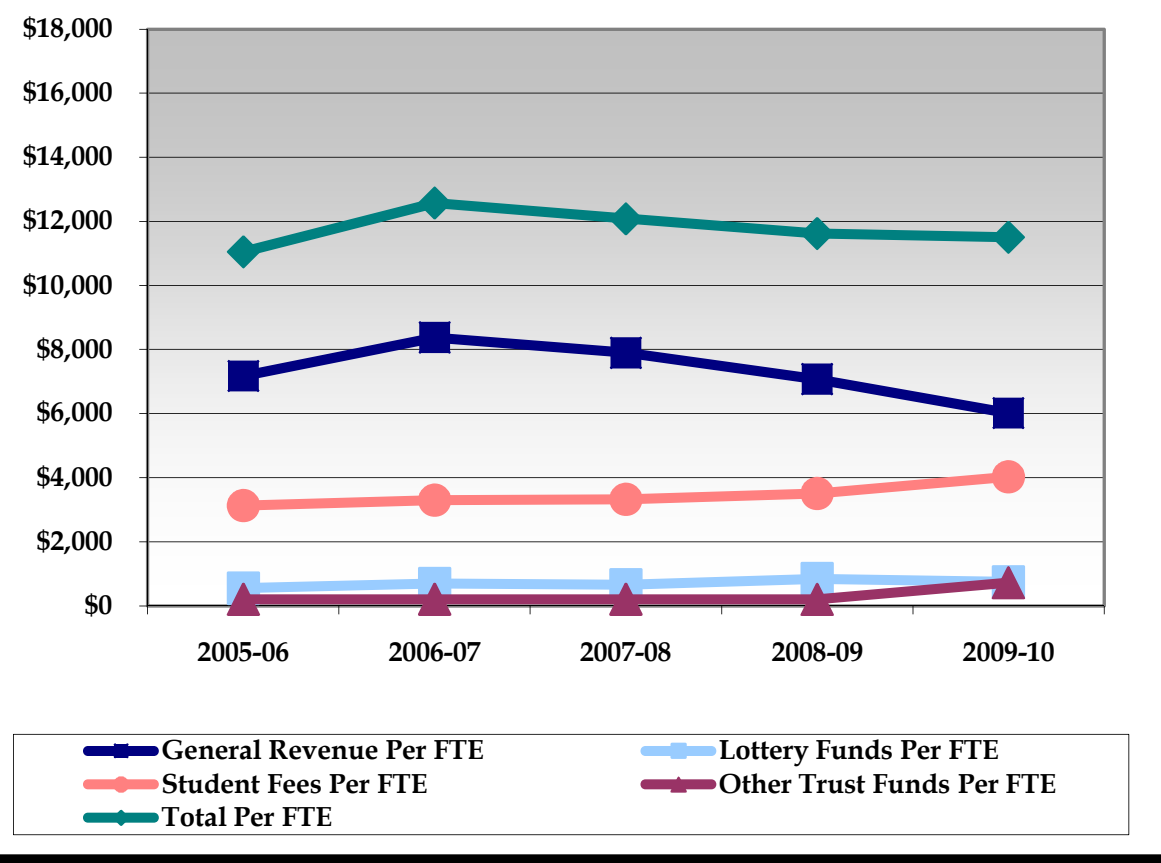

** FTE for this metric uses the standard IPEDS definition of FTE, equal to 30 credit hours for undergraduates and $\mathbf{2 4}$ for graduates. 


\section{Introduction}

\section{- Mission}

\section{DRAFT}

As Florida's only multi-campus university system, the University of South Florida is dedicated to adding value regionally, state-wide, nationally, and globally through: enhancing access to higher education; advancing research which benefits society; contributing to regional unification; leveraging distinctive regional advantages; promoting partnership opportunities; assuring academic program quality; and providing consistently high quality support programs and services.

\section{- Vision}

DRAFT

The USF System envisions itself as a leading multi-campus system of four separately accredited institutions with distinct and complementary missions that is a model for the next generation of university systems for the state of Florida and the nation.

\section{- Other Contextual Introductory Comments}

The University of South Florida System is comprised of campuses in Tampa, St. Petersburg, Sarasota-Manatee, and USF Polytechnic in Lakeland with a focus on five main strategic priorities: student success, research and innovation, community engagement, global literacy and impact, and integrated, interdisciplinary inquiry. The development of USF as a system offers some rewarding opportunities as the regional campuses develop their particular niche within the umbrella of USF and seek out relevant and appropriate Carnegie classifications.

The USF system embraces a unified vision of cooperative excellence with institutions, regional campuses and direct service organizations (DSOs) developing distinct and complementary missions that are consistent with the overall USF mission. The USF system deeply values existing collegial groups, including the Faculty Senate, Student Government, A\&P Council, and Staff Senate that constructively contribute to the USF system strategic plan. The USF system is committed to working collaboratively with such groups to identify, develop and refine best practices on matters of shared interest. USF System: http://system.usf.edu/index.asp
BOARD OF GOVERNORS - STATE UNIVERSITY SYSTEM GOAL 1: ACCESS TO AND PRODUCTION OF DEGREES

The USF System serves more than 47,000 students on campuses in Tampa, St. Petersburg, Sarasota-Manatee, and USF Polytechnic in Lakeland. The system is focused on five main strategic priorities: student success, research and innovation, community engagement, global literacy and impact, and integrated, interdisciplinary inquiry. USF offers 228 degree programs: 89 bachelors, 97 masters, 2 Eds degrees, 36 research doctoral programs, and four professional doctorates. In 2008-09, USF awarded 10,335 degrees, representing nearly one quarter of the university population.

USF is strategically shifting undergraduate enrollment to its regional campuses as part of the university's plan to expand access and more clearly define the missions of each campus. USF St. Petersburg, the only regional campus that admits freshmen, enrolled 349 new freshmen in Fall 2008, which is an increase of nearly 57 percent from the previous year's freshman class. USF Sarasota-Manatee and USF Polytechnic also saw impressive gains in their enrollments in 2008-09. The Sarasota-based campus total enrollment is 2,010, which is 10 percent gain from Fall 2007 year; and the Lakeland-based campus total enrollment is 1,316, a gain of 18 percent from 2007.

Even with increased admission standards for transfer students, USF remains one of the nation's top destinations for transfer students. Historically, USF enrolls the most students transferring from the state's public community colleges, demonstrating its commitment to supporting Florida's ' $2+2$ ' system and the unique needs of transfer students.

At the graduate level, impressive trends can be seen with regard to the number of doctoral degrees awarded, a measure of USF's growing commitment to graduate education and the creation of new knowledge through research, scholarship and creative activity. Continuing this trend prepares the nation's next generation of leaders, thinkers and scientists by replenishing the ranks of the professoriate for American higher education. 


\section{GOAL 1: ACCESS TO AND PRODUCTION OF DEGREES} (Continued)

Graduate and professional education at USF has been on a strong forward trajectory. Exemplary educational and research opportunities for graduate students have been developed to promote our next state, national, and global leaders.

Overall, one third of the USF System student body is comprised of students who identify themselves as races/ethnicities that are nonWhite. USF's student diversity is a hallmark of the institution and has been recognized by leading publications over the past several years.

\section{BOARD OF GOVERNORS - STATE UNIVERSITY SYSTEM GOAL 2: MEETING STATEWIDE PROFESSIONAL AND WORKFORCE NEEDS}

As a leading research university, USF offers a broad array of undergraduate and graduate degree programs preparing students to become leaders in business, industry, service, and research. Many degree programs align with state goals to meet professional and workforce needs, including education, health professions, the sciences, and emerging technologies.

Following the guidelines and selection of areas of strategic emphasis identified by the Board of Governors staff in consultation with business and industry groups, between 2004 and 2008, the USF System has experienced a positive growth trend in all identified areas (i.e., Education, Health Professions, STEM areas, Security \& Emergency Services, Globalization, and Regional Workforce Needs). From 2004 to 2008, USF has had a 30\% increase in total degrees awarded combined for all areas of strategic emphasis.

\begin{tabular}{|c|r|r|c|}
\hline SYSTEM & \multicolumn{1}{|c|}{2004} & 2008 & $\%$ Change \\
\hline Education & 107 & 112 & $5 \%$ \\
\hline Health Professions & 323 & 435 & $35 \%$ \\
\hline $\begin{array}{c}\text { Science, Technology, } \\
\text { Engineering, and Math }\end{array}$ & 1,074 & 1,395 & $30 \%$ \\
\hline Security \& Emergency Services & 333 & 412 & $24 \%$ \\
\hline Globalization & 355 & 470 & $32 \%$ \\
\hline Regional Workforce Needs & 1,073 & 1,414 & $32 \%$ \\
\hline $\begin{array}{c}\text { TOTAL: Areas of Strategic } \\
\text { Emphasis }\end{array}$ & 3,265 & 4,238 & $30 \%$ \\
\hline
\end{tabular}




\section{BOARD OF GOVERNORS - STATE UNIVERSITY SYSTEM GOAL 3: BUILDING WORLD-CLASS ACADEMIC PROGRAMS AND RESEARCH CAPACITY}

Research is a hallmark of every college, department and program at USF. It is an expectation and a privilege of every faculty member, whether it is sponsored by an external funding or carried out with support of university resources. As a result, there are scores of projects investigating basic research problems and tackling applied societal challenges that together all enhance our understanding of the world in the creation of new knowledge.

Research is a centerpiece of the university's strategic plan, is fundamental to the recruitment and retention of top faculty and gives a university distinction. Consistent with the USF Strategic Plan, the university has four internationally recognized research themes which span the entire campus: sustainability, integrated neurosciences, diabetes, and drug design, development and delivery.

USF's research enterprise is also remarkable on the national level. In fiscal year 2007, USF ranked $65^{\text {th }}$ of total research and development expenditures (external funding) for all universities and colleges and $44^{\text {th }}$ of all public institutions. USF also ranks $38^{\text {th }}$ in federal research expenditures for public universities and $62^{\text {nd }}$ for all universities. Last year, USF's funded research generated nearly $\$ 360$ million in external awards from federal, state, industry, foundation and other sponsors who are our partners in discovery and innovation that benefits Florida citizens, develops and commercializes products, knowhow and processes, and creates start-up companies and jobs.

The USF System is home to the Florida Center for Excellence for Biomolecular Identification and Targeted Therapeutics, which is focused on identifying, treating, and preventing life-threatening diseases. Such activities lead to economic development and create solutions to local, national and global problems.

Research firmly connects the university with the local Tampa Bay community through service, outreach and engagement activities, the corporate community through patenting and licensing of technology and targeted research, with other academics through collaborative and cooperative programs and globally through our relationships with research colleagues. Research also connects the system through multidisciplinary approaches to a common problem. Research provides opportunity to students and prepares them for success in their chosen fields or for graduate and professional education.

In 2008-09, three members of the USF faculty were identified as national academy members and eight received nationally prestigious faculty awards as defined by the Top American Research Universities (TARU). USF's commitment to applied research is evident by a 50 percent increase in the total number of patents issued since 2004 . 


\section{BOARD OF GOVERNORS - STATE UNIVERSITY SYSTEM GOAL 4: MEETING COMMUNITY NEEDS AND FULFILLING UNIQUE INSTITUTIONAL RESPONSIBILITIES}

The University of South Florida has rapidly grown from a small regional institution into a major research university and is continuing to evolve into a model for the next generation of university systems for the state of Florida and the nation. What was once known as a commuter school serving the Tampa area, the USF System today serves more than 47,000 students on campuses in Tampa, St.

Petersburg, Sarasota-Manatee, and USF Polytechnic in Lakeland, each with distinctive missions. While USF has expanded its residential experience, it still is the top destination nationally for students transferring from other institutions to complete their bachelor's degrees.

The system is focused on five main strategic priorities: student success, research and innovation, community engagement, global literacy and impact, and integrated, interdisciplinary inquiry. Consistent with the USF Strategic Plan, the university has four internationally recognized research themes which span the entire campus: sustainability, integrated neurosciences, diabetes, and drug design, development and delivery. Home to Florida's second public medical school, USF's focus on health education and research is a hallmark of the USF System's unique contributions to health disciplines and the public.

USF is one of only three Florida public universities classified by the Carnegie Foundation for the Advancement of Teaching in the top tier of research universities (RU/VH), a distinction attained by only $2.2 \%$ of all universities (96 total: 63 publics, 33 privates) and is also one of only 25 public research universities nationwide that holds both $\mathrm{RU} / \mathrm{VH}$ and Engaged designations.
Additional Information on Quality, Resources, Efficiencies, and

\section{Effectiveness}

USF's focus on integrated, interdisciplinary inquiry, one of the four pillars of the university's strategic plan, is evident both in instructional and research programs. From new doctoral programs to undergraduate research, graduate school partnerships, and community outreach initiatives, USF is positioned as an emerging global leader in a new way of approaching learning and discovery.

Recently, the Florida Board of Governors granted USF approval to establish new doctoral programs in history, government, and sociology. The programs are linked, which is quite different from traditional, discipline-based programs. They focus on building sustainable healthy communities in a global context. These new programs join existing dual and interdisciplinary degree programs both at the undergraduate and graduate level.

In recognition of USF's service in the community, it was placed on the Corporation for National and Community Service's President's Higher Education Community Service Honor Roll for exemplary service efforts and service to America's communities.

USF has formed strategic partnerships with some of the nation's leading research and development organizations, benefitting the university's research and educational programs as well as the state's economic vitality. Some of the partnerships include SRI, Draper Laboratory, H. Lee Moffitt Cancer Center \& Research Institute, The Byrd Alzheimer's Institute, New Energy Solar, Mote Marine Laboratory, and NanoCVD.

USF will continue to work with existing and forge new global partnerships. Currently these include many academic institutions around the world, as well as the Confucius Institute, the Japan Outreach Initiative, the Ghana Initiative, and the many other connections identified by USF World. 
Additional Information on Quality, Resources, Efficiencies, and Effectiveness (Continued)

USF will continue to expand opportunities for a diverse student body that includes students from different socio-economic backgrounds and ethnicities. In addition, USF will work with the Department of Veterans Affairs to have specialized academic guidance services for veterans taking advantages of the Post-9/11 Veterans Education Bill. The university also is moving toward signing an agreement that would allow veterans who are not Florida residents but who want to attend USF to waive out-of-state tuition costs not covered by the standard GI Bill benefits, with USF and the VA splitting the additional costs.

\section{Additional Resources}

Carnegie Classification

- Basic: RU/VH: Research Universities (very high research activity)

- Community Engagement: Outreach \& Partnerships

- Undergraduate Instructional Program:

CompDoc/MedVet: Comprehensive doctoral with medical/veterinary

- Graduate Instructional Program: Bal/HGC: Balanced arts \& sciences/professions, high graduate coexistence

- Enrollment Profile: HU: High undergraduate

- Undergraduate Profile: MFT4/S/HTI: Medium full-time four-year, selective, higher transfer-in

- Size and Setting: L4/NR: Large four-year, primarily nonresidential

http://www.carnegiefoundation.org/classifications/sub.asp? $\underline{k e y=748 \& \text { subkey }=13889 \& \text { start }=782}$

Voluntary System of Accountability College Portrait of

Undergraduate Education

http://www.collegeportraits.org/FL/USF

Common Data Set

http://www.ods.usf.edu/DSS/Resources/CDS.asp
College Navigator

http://nces.ed.gov/collegenavigator/?q=South+Florida\&s=F $\underline{\text { L\&id }=137351}$

University Institutional Research Unit

http://www.research.usf.edu/

University Strategic Plan

http://www.ods.usf.edu/plans/strategic/

University Data Sources

USF Planning, Performance and Accountability: http://www.ods.usf.edu/Plans/PPA/matrix.htm

\section{USF e-Profiles:}

http://ods.usf.edu/DSS/Resources/eProfiles.asp

\section{USF InfoCenter:}

http://usfweb3.usf.edu/infocenter/?report_category=STU

\section{USF Performance Dashboard:}

http://www.ods.usf.edu/Plans/PPA/dashboard.htm

\section{USF Peers:}

http://www.ie.usf.edu/Peer/ 


\section{Section 9 of Annual Report: Progress on Other Primary Institutional Goals and Metrics as Outlined in the University Work Plan}

\section{USF Tampa}

As the main research campus of the USF System, USF Tampa, which includes USF Health, USF Research Park, USF Downtown Center, and USF College of Marine Science, continues to work in alignment with its strategic plan goals in conjunction with the planning, performance, and accountability measures set forth by the institution.

A unique example of the integration of the USF Strategic Plan into the university's operations is the way USF incorporates the budget planning process into the implementation of the strategic planning process. USF aligns its budget with institutional strategic priorities through effectively communicating and engaging all stakeholders in a transparent, focused, and disciplined manner with a mind to preserving excellence; containing costs; leveraging efficiencies; generating new revenue; and maximizing performance.

USF's focus on integrated, interdisciplinary inquiry, one of the four pillars of the university's strategic plan, is evident both in instructional and research programs. From new doctoral programs to undergraduate research, graduate school partnerships, and community outreach initiatives, USF is positioned as an emerging global leader in a new way of approaching learning and discovery.

\section{See USF Tampa's SUS Annual Report for additional information}

\section{USF St. Petersburg}

The University of South Florida St. Petersburg's Strategic Plan for 2009-2013 includes six over-arching goals, each of which includes sub-goals. Each subgoal includes 1-, 3- and 5-year strategic objectives which have been structured to recognize budget realities while still advancing the overall mission of the institution. At this time, work groups have been established to address Year-1 strategic objectives in all six goals areas of the mission. Goals, sub-goals and strategic objectives are detailed below.

See USF St. Petersburg's SUS Annual Report for additional information

\section{USF Polytechnic}

The University of South Florida, Polytechnic has identified the following key accomplishments:

(1) Completed a USF Polytechnic Master Plan with update approved by the USF Board of Trustees in October 2009, and selected an internationally acclaimed architect; Dr. Santiago Calatrava whose concept for the new campus site is the first university built as a bioscape. This campus context will emerge as an unprecedented synthesis of architecture, design, engineering, agriculture and sustainability - a living example of the research, academic and social missions of USF Polytechnic.

(2) USF Polytechnic's colleges are now structured to reflect the Polytechnic's commitment to interdisciplinary engagement. Three colleges have been established: Technology and Innovation (housing academic divisions of Innovation Management, Engineering and Applied Sciences, and Information Technology); Human and Social Sciences (housing academic divisions of Education, Social Sciences and Allied Health Sciences); and Applied Arts and New Media (housing academic divisions of Architecture and Design, Technical and Professional Communication, and Digital Arts and Digital Media). A comprehensive faculty recruitment plan has also been developed for USF Polytechnic; 31 new faculty positions are targeted for 2009-2010 recruitment for the 2010-2011 academic year. Emphasis is on practitioner-scholars with experience in polytechnic institutions and capacity to deliver the polytechnic vision in teaching, research, and community engagement and impact. This academic structure and interdisciplinary faculty plan is an important part of the SACS Accreditation Application targeted for submission in February 2010.

(3) USF Polytechnic has established numerous collaborative public and private partnerships that enhanced funding, demonstrating the value of the campus and its potential contributions to the future economic growth and development of the region and beyond:

- Polk County Investment \$11.7 million.

- State of Florida Turnpike Authority Investment \$31.9 million; Williams Company \$9.4 million.

- Florida Department of Transportation Investment \$28 million.

- PECO State Funds \$31.2 million (received) and additional \$10 million anticipated in 2010; CITF funds of \$390,000; Investments from Private Sources $\$ 10.7$ million with anticipated FEGC match.

- PECO request \$5 million (on current CIP listing); Private Investment \$5 million (pledged over 3 yrs, first year received) eligible for FECG match.

- Private Investment $\$ 1$ million (incubators).

See USF Polytechnic SUS Annual Report for additional information 
Section 9 of Annual Report: Progress on Other Primary Institutional Goals and Metrics as Outlined in the University Work Plan

\section{(continued)}

\section{USF Sarasota-Manatee}

The University of South Florida Sarasota-Manatee is continuing its efforts towards the following goals:

(1) Learner-Centered Environment: Be a diverse, collaborative, and intellectually challenging campus with high quality academic programs and support services for students, faculty, staff, and community. The following action steps are necessary to achieve this goal: Maintain at least $60 \%$ full-time faculty delivering course work in every degree program by increasing the number of tenured/tenure-track, and promoted faculty through ongoing professional development and on-going review of faculty credentials and analysis of the SACS faculty roster; Successfully implement the USF

Sarasota-Manatee tenure system; and Increase the dollar figure by $10 \%$ over 2008-09 of grants for which faculty apply.

(2) Accreditation: Work toward institutional autonomy within the USF system with separate regional professional accreditations. Successful completion of application to the Southern Association of Colleges \& Schools.

See USF Sarasota-Manatee's SUS Annual Report for additional information 
List of Tables

Appendices

1 - Budget

2 - Federal Stimulus Dollars (ARRA)

3 - Other Core Resources

4 - Enrollment and Funding

5 - Undergraduate Education Data

A. Baccalaureate Degree Programs Implemented or Terminated

B. First-Year Persistence Rates

C. Undergraduate Progression and Graduation Rates

D. Baccalaureate Degrees Awarded

E. Baccalaureate Degrees Awarded in Areas of Strategic Emphasis

F. Baccalaureate Degrees Awarded to Underrepresented Groups

G. Baccalaureate Completions Without Excess Credit Hours

H. Undergraduate Course Offerings

I. Faculty Teaching Undergraduates

J. Undergraduate Instructional Faculty Compensation

K. Student-Faculty Ratios

L. Licensure Examination Pass Rates (Undergraduate)

M. Tuition Differential

6 - Graduate Education Data

A. Graduate Degree Programs Implemented or Terminated

B. Graduate Degrees Awarded

C. Graduate Degrees Awarded in Areas of Strategic Emphasis

D. Licensure Examination Pass Rates (Graduate)

7 - Research and Economic Development Data

A. Research and Development Expenditures

B. Other Research and Economic Development Outcomes

C. Centers of Excellence

D. Commercialization Assistance Grants

8 - Voluntary Support of Higher Education

9 - Progress on Other Primary Institutional Goals and Metrics As Outlined in the University Work Plan 


\begin{tabular}{|c|c|c|c|c|c|}
\hline \multicolumn{6}{|c|}{1 - Budget (Non-Medical) } \\
\hline & 2005-06 Actual & 2006-07 Actual & 2007-08 Actual & 2008-09 Actual & $\begin{array}{c}2009-10 \\
\text { Estimates }\end{array}$ \\
\hline \multicolumn{6}{|l|}{ Education and General } \\
\hline \multicolumn{6}{|l|}{ EEG Revenues } \\
\hline $\begin{array}{c}\text { State Funds (Recurring GR } \\
\text { \& Lottery) } \\
\end{array}$ & $\$ 261,153,771$ & $\$ 292,054,599$ & $\$ 291,429,103$ & $\$ 267,502,417$ & $\$ 241,509,153$ \\
\hline $\begin{array}{c}\text { State Funds (Non- } \\
\text { Recurring GR \& Lottery) }\end{array}$ & $\$ 500,000$ & $\$ 28,613,000$ & $\$ 8,802,803$ & $\$ 13,881,938$ & $\$ 1,585,515$ \\
\hline $\begin{array}{c}\text { Tuition (Resident/Non- } \\
\text { Resident) }\end{array}$ & $\$ 98,602,719$ & $\$ 104,174,513$ & $\$ 109,722,907$ & $\$ 112,352,760$ & $\$ 131,955,311$ \\
\hline Tuition Differential (UG) & $\$ 0$ & $\$ 0$ & $\$ 0$ & $\$ 2,626,024$ & $\$ 8,625,436$ \\
\hline $\begin{array}{l}\text { Other (Include Revenues } \\
\text { from Misc. Fees \& Fines) }\end{array}$ & $\$ 2,968,885$ & $\$ 3,259,132$ & $\$ 3,870,454$ & $\$ 3,862,283$ & $\$ 3,708,524$ \\
\hline $\begin{array}{c}\text { Phosphate Research Trust } \\
\text { Fund }\end{array}$ & $\$ 6,984,905$ & $\$ 7,141,734$ & $\$ 7,268,856$ & $\$ 7,287,963$ & $\$ 7,303,188$ \\
\hline Federal Stimulus Funds & $\$ 0$ & $\$ 0$ & $\$ 0$ & $\$ 0$ & $\$ 18,790,945$ \\
\hline \multirow[t]{2}{*}{ TOTAL } & $\$ 370,210,280$ & $\$ 435,242,978$ & $\$ 421,094,123$ & $\$ 407,513,385$ & $\$ 413,478,072$ \\
\hline & 2005-06 Actual & 2006-07 Actual & 2007-08 Actual & 2008-09 Actual & $\begin{array}{c}2009-10 \\
\text { Estimates } \\
\end{array}$ \\
\hline \multicolumn{6}{|l|}{ EEG Expenditures } \\
\hline Instruction/Research & $\$ 239,515,124$ & $\$ 259,117,057$ & $\$ 254,025,777$ & $\$ 232,420,538$ & $\$ 298,064,609$ \\
\hline $\begin{array}{c}\text { Institutes and Research } \\
\text { Centers } \\
\end{array}$ & $\$ 1,190,822$ & $\$ 1,234,810$ & $\$ 1,193,342$ & $\$ 1,024,089$ & $\$ 974,911$ \\
\hline PO\&M & $\$ 34,458,151$ & $\$ 37,822,475$ & $\$ 38,802,332$ & $\$ 36,124,122$ & $\$ 37,768,581$ \\
\hline $\begin{array}{c}\text { Administration and } \\
\text { Support Services }\end{array}$ & $\$ 18,159,663$ & $\$ 23,274,704$ & $\$ 21,181,757$ & $\$ 28,501,983$ & $\$ 40,274,912$ \\
\hline Radio/TV & $\$ 897,435$ & $\$ 953,802$ & $\$ 861,949$ & $\$ 815,056$ & $\$ 925,727$ \\
\hline Library/Audio Visual & $\$ 13,809,999$ & $\$ 14,549,948$ & $\$ 14,415,025$ & $\$ 14,141,123$ & $\$ 14,625,808$ \\
\hline Museums and Galleries & $\$ 750,947$ & $\$ 764,217$ & $\$ 740,454$ & $\$ 729,951$ & $\$ 652,679$ \\
\hline Agricultural Extension & $\$ 0$ & $\$ 0$ & $\$ 0$ & $\$ 0$ & $\$ 0$ \\
\hline Allied Clinics & $\$ 0$ & $\$ 0$ & $\$ 0$ & $\$ 0$ & $\$ 0$ \\
\hline Student Services & $\$ 19,405,458$ & $\$ 14,779,771$ & $\$ 22,958,049$ & $\$ 22,054,934$ & $\$ 21,017,602$ \\
\hline Intercollegiate Athletics & $\$ 288,260$ & $\$ 771,412$ & $\$ 513,486$ & $\$ 352,411$ & $\$ 375,739$ \\
\hline TOTAL & $\$ 328,475,859$ & $\$ 353,268,196$ & $\$ 354,692,171$ & $\$ 336,164,207$ & $\$ 414,680,568$ \\
\hline
\end{tabular}




\begin{tabular}{|c|c|c|c|c|c|}
\hline & 05-06 Actual & 06-07 Actual & 07-08 Actual & 08-09 Actual & $\begin{array}{c}2009-10 \\
\text { Estimates }\end{array}$ \\
\hline \multicolumn{6}{|l|}{ Contracts and Grants } \\
\hline Revenues & $\$ 322,486,960$ & $\$ 291,385,057$ & $\$ 260,378,731$ & $\$ 346,300,000$ & $\$ 322,486,960$ \\
\hline Expenditures & $\$ 294,744,902$ & $\$ 323,846,060$ & $\$ 293,512,444$ & $\$ 340,000,000$ & $\$ 294,744,902$ \\
\hline \multicolumn{6}{|l|}{ Auxiliary Enterprises } \\
\hline Revenues & $\$ 146,133,037$ & $\$ 147,145,183$ & $\$ 163,094,763$ & $\$ 171,361,009$ & $\$ 146,133,037$ \\
\hline Expenditures & $\$ 122,751,544$ & $\$ 142,263,107$ & $\$ 150,015,206$ & $\$ 240,123,445$ & $\$ 122,751,544$ \\
\hline \multicolumn{6}{|l|}{ Local Funds } \\
\hline Revenues & $\$ 185,129,970$ & $\$ 128,697,633$ & $\$ 145,745,675$ & $\$ 135,058,791$ & $\$ 185,129,970$ \\
\hline Expenditures & $\$ 180,579,643$ & $\$ 133,408,793$ & $\$ 133,879,634$ & $\$ 153,572,417$ & $\$ 180,579,643$ \\
\hline TOTAL REVENUES & $\$ 1,023,960,247$ & $\$ 1,002,470,851$ & $\$ 990,313,292$ & $\$ 1,060,233,185$ & $\$ 1,067,228,039$ \\
\hline TOTAL EXPENDITURES & $\$ 926,551,948$ & $\$ 952,786,156$ & $\$ 932,099,455$ & $\$ 1,069,860,069$ & $\$ 1,012,756,657$ \\
\hline
\end{tabular}

\section{2 - Federal Stimulus Dollars (ARRA)}

\begin{tabular}{|l|c|}
\hline \multicolumn{2}{|c|}{ 2 - Federal Stimulus Dollars (ARRA) } \\
\hline & Proposed 2009-10 \\
\hline \# Jobs Saved/Created & No HSC) \\
\hline Proposed Operating Budget Detail & $\$ 18,790,945$ \\
\hline Jobs Saved/Created & 0 \\
\hline Scholarships & 0 \\
\hline Library Resources & 0 \\
\hline Building Repairs/Alterations & 0 \\
\hline Motor Vehicles & 0 \\
\hline Printing & 0 \\
\hline Furniture \& Equipment & 0 \\
\hline Information Technology Equipment & 0 \\
\hline Financial Aid to Medical Students & \\
\hline Other: & $\$ 18,790,945$ \\
\hline TOTAL & \\
\hline
\end{tabular}




\begin{tabular}{|c|c|c|c|c|c|}
\hline \multicolumn{6}{|c|}{1 - Budget (Special Units-Health Science Center) } \\
\hline & 2005-06 Actual & 2006-07 Actual & 2007-08 Actual & 2008-09 Actual & $\begin{array}{c}2009-10 \\
\text { Estimates }\end{array}$ \\
\hline \multicolumn{6}{|l|}{ Health Science Center } \\
\hline \multicolumn{6}{|l|}{ HSC Revenues } \\
\hline $\begin{array}{c}\text { State Funds (Recurring GR } \\
\text { \& Lottery) } \\
\end{array}$ & $\$ 54,904,671$ & $\$ 65,740,706$ & $\$ 65,814,423$ & $\$ 62,041,950$ & $\$ 61,541,893$ \\
\hline $\begin{array}{c}\text { State Funds (Non- } \\
\text { Recurring GR \& Lottery) }\end{array}$ & $\$ 577,179$ & $\$ 1,002,981$ & $\$ 929,801$ & $\$ 635,338$ & $\$ 0$ \\
\hline $\begin{array}{c}\text { Tuition (Resident/Non- } \\
\text { Resident) } \\
\end{array}$ & $\$ 16,542,838$ & $\$ 17,974,839$ & $\$ 22,648,230$ & $\$ 26,347,362$ & $\$ 25,022,280$ \\
\hline Tuition Differential (UG) & $\$ 0$ & $\$ 0$ & $\$ 0$ & $\$ 111,799$ & $\$ 225,072$ \\
\hline $\begin{array}{l}\text { Other (Include Revenues } \\
\text { from Misc. Fees \& Fines) }\end{array}$ & $\$ 0$ & $\$ 4,678,832$ & $\$ 0$ & $\$ 0$ & $\$ 0$ \\
\hline $\begin{array}{c}\text { Phosphate Research Trust } \\
\text { Fund }\end{array}$ & $\$ 0$ & $\$ 0$ & $\$ 0$ & $\$ 0$ & $\$ 0$ \\
\hline Federal Stimulus Funds & $\$ 0$ & $\$ 0$ & $\$ 0$ & $\$ 0$ & $\$ 4,569,090$ \\
\hline \multirow[t]{2}{*}{ TOTAL } & $\$ 72,024,688$ & $\$ 89,397,358$ & $\$ 89,392,454$ & $\$ 89,136,449$ & $\$ 91,358,335$ \\
\hline & 2005-06 Actual & 2006-07 Actual & 2007-08 Actual & 2008-09 Actual & $\begin{array}{c}2009-10 \\
\text { Estimates } \\
\end{array}$ \\
\hline \multicolumn{6}{|l|}{ HSC Expenditures } \\
\hline Instruction/Research & $\$ 54,709,055$ & $\$ 63,448,633$ & $\$ 64,625,114$ & $\$ 64,047,565$ & $\$ 82,218,441$ \\
\hline $\begin{array}{c}\text { Institutes and Research } \\
\text { Centers } \\
\end{array}$ & $\$ 306,730$ & $\$ 202,840$ & $\$ 154,396$ & $\$ 1,153$ & $\$ 0$ \\
\hline PO\&M & $\$ 26,661$ & $\$ 90,778$ & $\$ 64,095$ & $\$ 262,695$ & $\$ 225,167$ \\
\hline $\begin{array}{c}\text { Administration and } \\
\text { Support Services }\end{array}$ & $\$ 5,275,321$ & $\$ 4,797,748$ & $\$ 5,200,070$ & $\$ 4,463,186$ & $\$ 3,602,325$ \\
\hline Radio/TV & $\$ 0$ & $\$ 0$ & $\$ 0$ & $\$ 0$ & $\$ 0$ \\
\hline Library/Audio Visual & $\$ 3,001,641$ & $\$ 3,008,725$ & $\$ 2,903,725$ & $\$ 2,787,282$ & $\$ 2,535,669$ \\
\hline Museums and Galleries & $\$ 0$ & $\$ 0$ & $\$ 0$ & $\$ 0$ & $\$ 0$ \\
\hline Agricultural Extension & $\$ 0$ & $\$ 0$ & $\$ 0$ & $\$ 0$ & $\$ 0$ \\
\hline Allied Clinics & $\$ 0$ & $\$ 0$ & $\$ 0$ & $\$ 0$ & $\$ 0$ \\
\hline Student Services & $\$ 0$ & $\$ 0$ & $\$ 0$ & $\$ 0$ & $\$ 0$ \\
\hline Intercollegiate Athletics & $\$ 0$ & $\$ 0$ & $\$ 0$ & $\$ 0$ & $\$ 0$ \\
\hline TOTAL & $\$ 63,319,408$ & $\$ 71,548,724$ & $\$ 72,947,400$ & $\$ 71,561,881$ & $\$ 88,581,602$ \\
\hline
\end{tabular}




\begin{tabular}{|c|c|c|c|c|c|}
\hline & 05-06 Actual & 06-07 Actual & 07-08 Actual & 08-09 Actual & 2009-10 \\
\hline \multicolumn{6}{|l|}{ Contracts and Grants } \\
\hline Revenues & $\$ 0$ & $\$ 0$ & $\$ 0$ & $\$ 0$ & $\$ 0$ \\
\hline Expenditures & $\$ 0$ & $\$ 0$ & $\$ 0$ & $\$ 0$ & $\$ 0$ \\
\hline \multicolumn{6}{|l|}{ Auxiliary Enterprises } \\
\hline Revenues & $\$ 0$ & $\$ 0$ & $\$ 0$ & $\$ 0$ & $\$ 0$ \\
\hline Expenditures & $\$ 0$ & $\$ 0$ & $\$ 0$ & $\$ 0$ & $\$ 0$ \\
\hline \multicolumn{6}{|l|}{ Local Funds } \\
\hline Revenues & $\$ 0$ & $\$ 0$ & $\$ 0$ & $\$ 0$ & $\$ 0$ \\
\hline Expenditures & $\$ 0$ & $\$ 0$ & $\$ 0$ & $\$ 0$ & $\$ 0$ \\
\hline \multicolumn{6}{|l|}{ Faculty Practice } \\
\hline \multicolumn{6}{|l|}{ Revenues } \\
\hline \multicolumn{6}{|l|}{ Expenditures } \\
\hline TOTAL REVENUES & $\$ 72,024,688$ & $\$ 89,397,358$ & $\$ 89,392,454$ & $\$ 89,136,449$ & $\$ 91,358,335$ \\
\hline TOTAL EXPENDITURES & $\$ 63,319,408$ & $\$ 71,548,724$ & $\$ 72,947,400$ & $\$ 71,561,881$ & $\$ 88,581,602$ \\
\hline
\end{tabular}




\begin{tabular}{|l|c|}
\hline \multicolumn{2}{|c|}{ 2 - Federal Stimulus Dollars (ARRA) } \\
\hline & Proposed 2009-10 \\
\hline & USF-HSC \\
\hline \# Jobs Saved/Created & 54 \\
\hline Proposed Operating Budget Detail & $\$ 4,569,090$ \\
\hline Jobs Saved/Created & 0 \\
\hline Scholarships & 0 \\
\hline Library Resources & 0 \\
\hline Building Repairs/Alterations & 0 \\
\hline Motor Vehicles & 0 \\
\hline Printing & 0 \\
\hline Furniture \& Equipment & 0 \\
\hline Information Technology Equipment & 0 \\
\hline Financial Aid to Medical Students & 0 \\
\hline Other: & $\$ 4,569,090$ \\
\hline TOTAL & 0 \\
\hline
\end{tabular}




\begin{tabular}{|c|c|c|c|c|c|}
\hline \multicolumn{5}{|c|}{3 - Other Core Resources (excludes Health Science Center) } \\
\hline $\begin{array}{c}\text { Funding per Student FTE } \\
\text { (US Definition) }\end{array}$ & $2005-06$ & $2006-07$ & $2007-08$ & $2008-09$ & $2009-10$ \\
\hline General Revenue per FTE & $\$ 7,172$ & $\$ 8,375$ & $\$ 7,896$ & $\$ 7,075$ & $\$ 6,012$ \\
\hline Lottery Funds per FTE & $\$ 547$ & $\$ 694$ & $\$ 653$ & $\$ 844$ & $\$ 744$ \\
\hline Other Trust Funds per FTE & $\$ 206$ & $\$ 207$ & $\$ 207$ & $\$ 205$ & $\$ 725$ \\
\hline Student Fees per FTE & $\$ 3,128$ & $\$ 3,298$ & $\$ 3,327$ & $\$ 3,502$ & $\$ 4,027$ \\
\hline Total per FTE Student & $\$ 11,053$ & $\$ 12,574$ & $\$ 12,083$ & $\$ 11,626$ & $\$ 11,508$ \\
\hline
\end{tabular}

** FTE for this metric uses the standard IPEDS definition of FTE, equal to 30 credit hours for undergraduates and $\mathbf{2 4}$ for graduates.

\begin{tabular}{|c|c|c|c|c|c|c|c|c|c|c|}
\hline \multirow{2}{*}{ Personnel Headcount } & \multicolumn{2}{|c|}{ Fall 2004} & \multicolumn{2}{|c|}{ Fall 2005} & \multicolumn{2}{|c|}{ Fall 2006} & \multicolumn{2}{|c|}{ Fall 2007} & \multicolumn{2}{|c|}{ Fall 2008} \\
\hline & FT & PT & FT & PT & FT & PT & FT & PT & FT & PT \\
\hline $\begin{array}{c}\text { Total Tenure/ Tenure-track } \\
\text { Faculty }\end{array}$ & 1,159 & 52 & 1,204 & 87 & 1,210 & 77 & 1,175 & 78 & 1,103 & 80 \\
\hline $\begin{array}{c}\text { Total Non-Tenure Track } \\
\text { Faculty }\end{array}$ & 484 & 109 & 488 & 156 & 543 & 165 & 582 & 170 & 479 & 154 \\
\hline $\begin{array}{c}\text { Total Graduate Assistants/ } \\
\text { Associates }\end{array}$ & & 628 & & 1,692 & & 1,752 & & 1,725 & & 1,774 \\
\hline $\begin{array}{l}\text { Total Executive/ Ad- } \\
\text { ministrative/ Managerial }\end{array}$ & 493 & 10 & 504 & 12 & 528 & 16 & 603 & 19 & 606 & 15 \\
\hline Total Other Professional & 1,984 & 164 & 1,792 & 118 & 1,829 & 101 & 1,715 & 93 & 1,710 & 72 \\
\hline Total Non-Professional & 1,681 & 44 & 1,640 & 30 & 1,686 & 31 & 1,792 & 41 & 1,731 & 40 \\
\hline Space & Fall & 2004 & Fall & 2005 & Fall & 2006 & Fall & 007 & Fall & 008 \\
\hline $\begin{array}{c}\text { Space Utilization } \\
\text { Percentage (Classrooms) }\end{array}$ & 118 & & 112 & & & .59 & 117 & & 127 & \\
\hline
\end{tabular}




\section{4 - Enrollment and Funding}

\begin{tabular}{|c|c|c|c|c|c|c|}
\hline $\begin{array}{l}\text { For entire } \\
\text { institution: } \\
\text { Annual FTE }\end{array}$ & $\begin{array}{l}\text { Funded } \\
2007-08\end{array}$ & $\begin{array}{r}2007-08 \\
\text { Actual }\end{array}$ & $\begin{array}{l}\text { Funded } \\
\text { 2008-09 }\end{array}$ & $\begin{array}{r}2008-09 \\
\text { Actual }\end{array}$ & $\begin{array}{l}\text { Funded } \\
2009-10\end{array}$ & $\begin{array}{c}2009-10 \\
\text { Estimated }\end{array}$ \\
\hline $\begin{array}{c}\text { FL Resident } \\
\text { Lower }\end{array}$ & 9,378 & 9,182 & 9,275 & 8,979 & 9,378 & 8,983 \\
\hline $\begin{array}{c}\text { FL Resident } \\
\text { Upper }\end{array}$ & 13,361 & 13,309 & 12,777 & 13,849 & 13,361 & 13,999 \\
\hline $\begin{array}{c}\text { FL Resident } \\
\text { Grad I }\end{array}$ & 3,680 & 3,796 & 3,185 & 4,006 & 3,680 & 4,074 \\
\hline $\begin{array}{c}\text { FL Resident } \\
\text { Grad II }\end{array}$ & 854 & 882 & 622 & 859 & 854 & 906 \\
\hline $\begin{array}{c}\text { Total FL } \\
\text { Resident }\end{array}$ & 27,273 & 27,168 & 25,859 & 27,694 & 27,273 & 27,962 \\
\hline $\begin{array}{c}\text { Non-Res. } \\
\text { Lower }\end{array}$ & & 387 & & 330 & & 349 \\
\hline $\begin{array}{c}\text { Non-Res. } \\
\text { Upper }\end{array}$ & & 416 & & 415 & & 421 \\
\hline $\begin{array}{c}\text { Non-Res. Grad } \\
\text { I }\end{array}$ & & 371 & & 374 & & 387 \\
\hline $\begin{array}{c}\text { Non-Res. Grad } \\
\text { II } \\
\end{array}$ & & 244 & & 232 & & 214 \\
\hline Total Non-Res. & 1,400 & 1,418 & 1,302 & 1,351 & 1,400 & 1,371 \\
\hline Total Lower & & 9,569 & & 9,309 & & 9,332 \\
\hline Total Upper & & 13,725 & & 14,264 & & 14,420 \\
\hline Total Grad I & & 4,167 & & 4,444 & & 4,461 \\
\hline Total Grad II & & 1,125 & & 1,027 & & 1,120 \\
\hline Total FTE & 28,673 & 28,586 & 27,161 & 29,045 & 27,161 & 29,333 \\
\hline $\begin{array}{c}\text { Total FTE - US } \\
\text { Definition* }\end{array}$ & 38,231 & 38,115 & 36,215 & 38,727 & 36,215 & 39,111 \\
\hline
\end{tabular}




\begin{tabular}{|c|c|c|c|c|c|c|}
\hline Annual FTE & $\begin{array}{l}\text { Funded } \\
2007-08 \\
\end{array}$ & $\begin{array}{r}2007-08 \\
\text { Actual } \\
\end{array}$ & $\begin{array}{l}\text { Funded } \\
2008-09 \\
\end{array}$ & $\begin{array}{c}2008-09 \\
\text { Actual } \\
\end{array}$ & $\begin{array}{r}\text { Funded } \\
2009-10 \\
\end{array}$ & $\begin{array}{c}2009-10 \\
\text { Estimated } \\
\end{array}$ \\
\hline $\begin{array}{l}\text { FL Resident } \\
\text { Medical } \\
\text { Headcount }\end{array}$ & 480 & 470 & 480 & 465 & 480 & 472 \\
\hline $\begin{array}{l}\text { Non-Res. } \\
\text { Medical } \\
\text { Headcount }\end{array}$ & & 11 & & 17 & & 8 \\
\hline $\begin{array}{c}\text { Total Medical } \\
\text { Headcount }\end{array}$ & & 481 & & 482 & & 480 \\
\hline $\begin{array}{l}\text { FL Resident } \\
\text { Dentistry } \\
\text { Headcount }\end{array}$ & $\$ 0$ & $\$ 0$ & $\$ 0$ & $\$ 0$ & $\$ 0$ & $\$ 0$ \\
\hline $\begin{array}{l}\text { Non-Res. } \\
\text { Dentistry } \\
\text { Headcount }\end{array}$ & & $\$ 0$ & & $\$ 0$ & & $\$ 0$ \\
\hline $\begin{array}{c}\text { Total Dentistry } \\
\text { Headcount }\end{array}$ & & $\$ 0$ & & $\$ 0$ & & $\$ 0$ \\
\hline $\begin{array}{c}\text { FL Resident } \\
\text { Veterinary } \\
\text { Medicine } \\
\text { Headcount }\end{array}$ & $\$ 0$ & $\$ 0$ & $\$ 0$ & $\$ 0$ & $\$ 0$ & $\$ 0$ \\
\hline $\begin{array}{l}\text { Non-Res. } \\
\text { Veterinary } \\
\text { Medicine } \\
\text { Headcount }\end{array}$ & & $\$ 0$ & & $\$ 0$ & & $\$ 0$ \\
\hline $\begin{array}{c}\text { Total } \\
\text { Veterinary } \\
\text { Medicine } \\
\text { Headcount } \\
\end{array}$ & & $\$ 0$ & & $\$ 0$ & & $\$ 0$ \\
\hline $\begin{array}{c}\text { Total Non-Res. } \\
\text { Med., Den., } \\
\text { Vet. Medicine } \\
\text { Headcount }\end{array}$ & $\$ 0$ & $\$ 0$ & $\$ 0$ & $\$ 0$ & $\$ 0$ & $\$ 0$ \\
\hline \multicolumn{7}{|c|}{$\begin{array}{l}\text { * Use FL - SUS definitions of FTE (Undergraduate FTE }=40 \text { and Graduate FTE }=32 \text { credit hours per FTE) for all items } \\
\text { except the row named Total FTE- US Definition. For this row, use Undergraduate FTE }=30 \text { and Graduate FTE }=24 \\
\text { credit hours. }\end{array}$} \\
\hline
\end{tabular}




\section{4 - Enrollment and Funding (Continued)}

For each distinct location (main, branch, site, regional campus) with> 150 FTE. Add charts, if needed.

SITE: Tampa

\begin{tabular}{|c|c|c|c|}
\hline FTE & $\begin{array}{r}2007-08 \\
\text { Actual }\end{array}$ & $\begin{array}{c}2008-09 \\
\text { Actual }\end{array}$ & $\begin{array}{c}2009-10 \\
\text { Estimated }\end{array}$ \\
\hline Lower & 8,539 & 8,230 & 8,531 \\
\hline Upper & 9,872 & 10,202 & 11,092 \\
\hline Grad I & 2,837 & 2,793 & 3,848 \\
\hline Grad II & 910 & 878 & 1120 \\
\hline Total & 22,158 & 22,103 & 24,591 \\
\hline
\end{tabular}

SITE: USF Health

FTE

\begin{tabular}{|c|c}
\hline Lower & 359 \\
\hline Upper & 871 \\
\hline Grad I & 754 \\
\hline Grad II & 210 \\
\hline Total & $\mathbf{2 1 9 4}$ \\
\hline
\end{tabular}

SITE: Polytechnic

FTE

\begin{tabular}{c} 
Lower \\
Upper \\
Grad I \\
Grad II \\
Total \\
\hline
\end{tabular}

2007-08
Actual

\section{7-08}

Actual

\begin{tabular}{c}
11 \\
596 \\
111 \\
1 \\
719 \\
\hline
\end{tabular}

SITE: Sarasota Branch

FTE

\begin{tabular}{l} 
Lower \\
Upper \\
Grad I \\
Grad II \\
\hline Total
\end{tabular}

\section{7-08 \\ Actual}

\section{8-09 \\ Actual}

\begin{tabular}{c}
316 \\
844 \\
978 \\
209 \\
\hline 2347
\end{tabular}

2009-10

Estimated

\begin{tabular}{c}
311 \\
847 \\
968 \\
\hline 220 \\
\hline 2346 \\
\hline
\end{tabular}




\begin{tabular}{|c|c|c|c|}
\hline \multicolumn{4}{|c|}{4 - Enrollment and Funding (Continued) } \\
\hline SITE: St. Peters & & & \\
\hline FTE & $\begin{array}{r}\text { 2007-08 } \\
\text { Actual }\end{array}$ & $\begin{array}{r}\text { 2008-09 } \\
\text { Actual }\end{array}$ & $\begin{array}{c}2009-10 \\
\text { Estimated }\end{array}$ \\
\hline Lower & 660 & 741 & 770 \\
\hline Upper & 1,506 & 1,547 & 1,530 \\
\hline Grad I & 285 & 296 & 305 \\
\hline Grad II & 4 & 1 & 0 \\
\hline Total & 2,454 & 2,585 & 2,605 \\
\hline
\end{tabular}




\begin{tabular}{|c|c|c|c|c|c|}
\hline \multicolumn{6}{|c|}{5 - Undergraduate Education Data } \\
\hline $\begin{array}{c}\text { 5A. Baccalaureate } \\
\text { Degree Programs } \\
\text { Implemented or } \\
\text { Terminated } \\
\text { Title and Program } \\
\text { Level }\end{array}$ & $\begin{array}{c}\text { New } \\
\text { Program or } \\
\text { Termina- } \\
\text { tion? }\end{array}$ & $\begin{array}{l}\text { Date } \\
\text { Approved } \\
\text { by UBOT }\end{array}$ & $\begin{array}{c}\text { Date } \\
\text { Approved } \\
\text { by BOG, if } \\
\text { Needed }\end{array}$ & $\begin{array}{l}\text { Implementa- } \\
\text { tion Date, if } \\
\text { New }\end{array}$ & $\begin{array}{l}\text { Program } \\
\text { CIP Code }\end{array}$ \\
\hline General Studies & $\overline{\mathrm{New}}$ & $6 / 12 / 2008$ & $\mathrm{n} / \mathrm{a}$ & Fall 2008 & 24.0102 \\
\hline $\begin{array}{c}\text { Education, Multi-Cert (St. } \\
\text { Pete) }\end{array}$ & New & $6 / 12 / 2008$ & $\mathrm{n} / \mathrm{a}$ & Fall 2008 & 13.1206 \\
\hline Graphic Design & New & $7 / 16 / 2008$ & $\mathrm{n} / \mathrm{a}$ & Fall 2008 & 50.0409 \\
\hline $\begin{array}{l}\text { Long Term Care } \\
\text { Administration }\end{array}$ & New & $11 / 4 / 2008$ & $\mathrm{n} / \mathrm{a}$ & Fall 2008 & 51.0701 \\
\hline General Studies & New & $6 / 12 / 2008$ & $\mathrm{n} / \mathrm{a}$ & \begin{tabular}{|l|} 
Fall 2008 \\
\end{tabular} & 24.0102 \\
\hline \multicolumn{6}{|c|}{ 5B. Successful First-Year Persistence Rates } \\
\hline $\begin{array}{c}\text { YEAR OF SUS } \\
\text { MATRICULATION }\end{array}$ & 2003 & 2004 & 2005 & 2006 & 2007 \\
\hline $\begin{array}{c}\text { Full-Time FTIC } \\
\text { Cohort (Fall/Summer- } \\
\text { Fall) Size }\end{array}$ & 4,976 & 4,568 & 4,349 & 4,399 & 4143 \\
\hline $\begin{array}{c}\text { Percentage Enrolled in } \\
\text { Same IHE After One } \\
\text { Year }\end{array}$ & $83.1 \%$ & $84.3 \%$ & $82.5 \%$ & $83.6 \%$ & $87.3 \%$ \\
\hline
\end{tabular}




\begin{tabular}{|c|c|c|c|c|c|}
\hline \multicolumn{6}{|c|}{ 5C. Successful Undergraduate Progression and Graduation Rates } \\
\hline $\begin{array}{c}\text { YEAR OF SUS } \\
\text { MATRICULATION }\end{array}$ & 1999 & 2000 & 2001 & 2002 & 2003 \\
\hline $\begin{array}{c}\text { FTIC Cohort } \\
\text { (Fall/Summer-Fall) } \\
\text { Size }\end{array}$ & 3,736 & 3,919 & 4,498 & 4,488 & 5212 \\
\hline $\begin{array}{c}\text { Percentage Graduated } \\
\text { from Same IHE } \\
\text { Within } 4 \text { Years }\end{array}$ & $19.2 \%$ & $19.4 \%$ & $18.4 \%$ & $20.2 \%$ & $20.2 \%$ \\
\hline $\begin{array}{c}\text { Percentage Graduated } \\
\text { from Other SUS IHE } \\
\text { Within } 4 \text { Years }\end{array}$ & $1.6 \%$ & $1.9 \%$ & $1.2 \%$ & $1.5 \%$ & $1.5 \%$ \\
\hline $\begin{array}{c}\text { Percentage Enrolled in } \\
\text { Same IHE After } 4 \\
\text { Years } \\
\end{array}$ & $41.0 \%$ & $43.1 \%$ & $44.9 \%$ & $42.4 \%$ & $42.4 \%$ \\
\hline $\begin{array}{c}\text { Percentage Enrolled in } \\
\text { Other SUS IHE After } \\
4 \text { Years } \\
\end{array}$ & $4.7 \%$ & $4.6 \%$ & $3.8 \%$ & $3.9 \%$ & $3.9 \%$ \\
\hline $\begin{array}{c}\text { TOTAL 4-Year } \\
\text { Success and Progress } \\
\text { Rate (Graduated or } \\
\text { Enrolled in SUS) }\end{array}$ & $66.5 \%$ & $69.0 \%$ & $68.3 \%$ & $67.1 \%$ & $68.0 \%$ \\
\hline
\end{tabular}




\begin{tabular}{|c|c|c|c|c|c|}
\hline $\begin{array}{c}\text { Percentage Graduated } \\
\text { from Same IHE } \\
\text { Within } 6 \text { Years }\end{array}$ & $45.4 \%$ & $46.3 \%$ & $46.3 \%$ & $46.5 \%$ & $46.9 \%$ \\
\hline $\begin{array}{c}\text { Percentage Graduated } \\
\text { from Other SUS IHE } \\
\text { Within } 6 \text { Years }\end{array}$ & $4.7 \%$ & $4.6 \%$ & $3.8 \%$ & $4.1 \%$ & $4.3 \%$ \\
\hline $\begin{array}{c}\text { Percentage Enrolled in } \\
\text { Same IHE After } 6 \\
\text { Years }\end{array}$ & $9.6 \%$ & $10.9 \%$ & $11.1 \%$ & $10.7 \%$ & $11.0 \%$ \\
\hline $\begin{array}{c}\text { Percentage Enrolled in } \\
\text { Other SUS IHE After } \\
6 \text { Years } \\
\end{array}$ & $4.7 \%$ & $4.6 \%$ & $1.9 \%$ & $1.5 \%$ & $1.5 \%$ \\
\hline $\begin{array}{c}\text { TOTAL 6-Year } \\
\text { Success and Progress } \\
\text { Rate (Graduated or } \\
\text { Enrolled in SUS) }\end{array}$ & $61.4 \%$ & $63.8 \%$ & $63.1 \%$ & $62.6 \%$ & $63.7 \%$ \\
\hline $\begin{array}{c}\text { YEAR OF SUS } \\
\text { MATRICULATION }\end{array}$ & 2001 & 2002 & 2003 & 2004 & 2005 \\
\hline $\begin{array}{l}\text { AA Transfer Cohort } \\
\text { (Fall/Summer-Fall) } \\
\text { Size }\end{array}$ & 1,810 & 1,863 & 1,751 & 1,914 & 2,067 \\
\hline $\begin{array}{c}\text { Percentage Graduated } \\
\text { from Same IHE } \\
\text { Within } 2 \text { Years }\end{array}$ & $24.6 \%$ & $25.2 \%$ & $24.8 \%$ & $27.7 \%$ & $26.4 \%$ \\
\hline $\begin{array}{c}\text { Percentage Graduated } \\
\text { from Other SUS IHE } \\
\text { Within } 2 \text { Years }\end{array}$ & $0.2 \%$ & $0.1 \%$ & $0.2 \%$ & $0.3 \%$ & $0.2 \%$ \\
\hline $\begin{array}{c}\text { Percentage Enrolled in } \\
\text { Same IHE After } 2 \\
\text { Years } \\
\end{array}$ & $58.7 \%$ & $57.5 \%$ & $60.1 \%$ & $57.5 \%$ & $58.9 \%$ \\
\hline $\begin{array}{c}\text { Percentage Enrolled in } \\
\text { Other SUS IHE After } \\
2 \text { Years }\end{array}$ & $1.4 \%$ & $1.6 \%$ & $1.1 \%$ & $2.0 \%$ & $1.8 \%$ \\
\hline $\begin{array}{c}\text { TOTAL 2-Year } \\
\text { Success and Progress } \\
\text { Rate (Graduated or } \\
\text { Enrolled in SUS) }\end{array}$ & $84.9 \%$ & $84.4 \%$ & $86.2 \%$ & $87.5 \%$ & $87.3 \%$ \\
\hline
\end{tabular}




\begin{tabular}{|c|c|c|c|c|c|}
\hline $\begin{array}{c}\text { Percentage Graduated } \\
\text { from Same IHE } \\
\text { Within } 4 \text { Years }\end{array}$ & $59.7 \%$ & $60.5 \%$ & $62.1 \%$ & $64.6 \%$ & $62.8 \%$ \\
\hline $\begin{array}{c}\text { Percentage Graduated } \\
\text { from Other SUS IHE } \\
\text { Within } 4 \text { Years }\end{array}$ & $1.0 \%$ & $1.4 \%$ & $1.1 \%$ & $1.4 \%$ & $1.4 \%$ \\
\hline $\begin{array}{c}\text { Percentage Enrolled in } \\
\text { Same IHE After } 4 \\
\text { Years }\end{array}$ & $12.4 \%$ & $11.1 \%$ & $12.6 \%$ & $10.9 \%$ & $12.7 \%$ \\
\hline $\begin{array}{c}\text { Percentage Enrolled in } \\
\text { Other SUS IHE After } \\
4 \text { Years }\end{array}$ & $1.0 \%$ & $1.3 \%$ & $0.5 \%$ & $1.2 \%$ & $0.7 \%$ \\
\hline $\begin{array}{l}\text { TOTAL 4-Year } \\
\text { Success and Progress } \\
\text { Rate (Graduated or } \\
\text { Enrolled in SUS) }\end{array}$ & $74.1 \%$ & $74.2 \%$ & $76.4 \%$ & $78.1 \%$ & $77.6 \%$ \\
\hline $\begin{array}{c}\text { YEAR OF SUS } \\
\text { MATRIC. }\end{array}$ & 2000 & 2001 & 2002 & 2003 & 2004 \\
\hline $\begin{array}{c}\text { Other Transfer Cohort } \\
\text { (Fall/Summer-Fall) } \\
\text { Size }\end{array}$ & 2,395 & 2,275 & 2,217 & 2,399 & 2,495 \\
\hline $\begin{array}{c}\text { Percentage Graduated } \\
\text { from Same IHE } \\
\text { Within } 5 \text { Years }\end{array}$ & $56.3 \%$ & $54.2 \%$ & $52.1 \%$ & $55.5 \%$ & $55.6 \%$ \\
\hline $\begin{array}{c}\text { Percentage Graduated } \\
\text { from Other SUS IHE } \\
\text { Within } 5 \text { Years }\end{array}$ & $2.6 \%$ & $1.6 \%$ & $2.2 \%$ & $2.0 \%$ & $1.6 \%$ \\
\hline $\begin{array}{c}\text { Percentage Enrolled in } \\
\text { Same IHE After } 5 \\
\text { Years }\end{array}$ & $6.8 \%$ & $6.9 \%$ & $6.6 \%$ & $7.1 \%$ & $6.7 \%$ \\
\hline $\begin{array}{c}\text { Percentage Enrolled in } \\
\text { Other SUS IHE After } \\
5 \text { Years }\end{array}$ & $0.5 \%$ & $0.4 \%$ & $0.7 \%$ & $1.7 \%$ & $0.8 \%$ \\
\hline $\begin{array}{c}\text { TOTAL 5-Year } \\
\text { Success and Progress } \\
\text { Rate (Graduated or } \\
\text { Enrolled in SUS) }\end{array}$ & $66.2 \%$ & $63.1 \%$ & $62.8 \%$ & $65.3 \%$ & $64.7 \%$ \\
\hline
\end{tabular}




\begin{tabular}{|c|c|c|c|c|c|}
\hline $\begin{array}{l}\text { 5D. Baccalaureate } \\
\text { Degrees Awarded }\end{array}$ & 2004-2005 & 2005-2006 & 2006-2007 & 2007-2008 & 2008-2009 \\
\hline Baccalaureate Degrees & 5,719 & 6,129 & 6,736 & 7,086 & 7,479 \\
\hline \multirow{2}{*}{$\begin{array}{c}\text { 5E. Baccalaureate } \\
\text { Degrees Awarded in } \\
\text { Areas of Strategic } \\
\text { Emphasis }\end{array}$} & \multicolumn{5}{|c|}{$\begin{array}{l}\text { Areas of Strategic Emphasis: Specific degree programs will be } \\
\text { identified for each university. [UNDUPLICATED COUNT] }\end{array}$} \\
\hline & 2004-2005 & 2005-2006 & 2006-2007 & 2007-2008 & 2008-2009 \\
\hline Education & 107 & 97 & 94 & 105 & 112 \\
\hline Health Professions & 323 & 339 & 443 & 420 & 435 \\
\hline $\begin{array}{c}\text { Science, Technology, } \\
\text { Engineering, and } \\
\text { Math }\end{array}$ & 1074 & 1127 & 1255 & 1299 & 1395 \\
\hline $\begin{array}{c}\text { Security \& Emergency } \\
\text { Services }\end{array}$ & 333 & 337 & 366 & 394 & 412 \\
\hline Globalization & 355 & 377 & 427 & 445 & 470 \\
\hline $\begin{array}{l}\text { Regional Workforce } \\
\text { Needs }\end{array}$ & 1073 & 1122 & 1231 & 1311 & 1414 \\
\hline $\begin{array}{l}\text { TOTAL: Areas of } \\
\text { Strategic Emphasis }\end{array}$ & 3265 & 3399 & 3816 & 3974 & 4238 \\
\hline
\end{tabular}




\begin{tabular}{|c|c|c|c|c|c|}
\hline $\begin{array}{c}\text { 5F. Baccalaureate } \\
\text { Degrees Awarded to } \\
\text { Underrepresented } \\
\text { Groups }\end{array}$ & 2004-2005 & 2005-2006 & 2006-2007 & 2007-2008 & 2008-2009 \\
\hline $\begin{array}{c}\text { \# of Baccalaureate } \\
\text { Degrees Awarded to } \\
\text { Black Non-Hispanic } \\
\text { Students }\end{array}$ & 592 & 683 & 774 & 811 & 899 \\
\hline $\begin{array}{c}\% \text { of Total } \\
\text { Baccalaureate Degrees } \\
\text { (Excluding Those } \\
\text { Awarded to Non- } \\
\text { Resident Aliens and } \\
\text { Unreported) Awarded } \\
\text { to Black Non-Hispanic } \\
\text { Students }\end{array}$ & $11.0 \%$ & $11.7 \%$ & $12.1 \%$ & $12.0 \%$ & $12.40 \%$ \\
\hline $\begin{array}{c}\text { \# of Baccalaureate } \\
\text { Degrees Awarded to } \\
\text { Hispanic Students } \\
\end{array}$ & 538 & 595 & 685 & 764 & 875 \\
\hline $\begin{array}{l}\% \text { of Total } \\
\text { Baccalaureate Degrees } \\
\text { (Excluding Those } \\
\text { Awarded to Non- } \\
\text { Resident Aliens and } \\
\text { Unreported) Awarded } \\
\text { to Hispanic Students }\end{array}$ & $10.0 \%$ & $10.2 \%$ & $10.7 \%$ & $11.3 \%$ & $12.1 \%$ \\
\hline $\begin{array}{l}\text { Number of } \\
\text { Baccalaureate Degrees } \\
\text { Awarded to PELL } \\
\text { Recipients (Defined as } \\
\text { Those Receiving PELL } \\
\text { Within } 6 \text { Years of } \\
\text { Graduation) }\end{array}$ & 2,131 & 2,301 & 2,605 & 2,613 & 2770 \\
\hline $\begin{array}{l}\% \text { of Total } \\
\text { Baccalaureate Degrees } \\
\text { (Excluding Those } \\
\text { Awarded to Non- } \\
\text { Resident Aliens) } \\
\text { Awarded to PELL } \\
\text { Recipients (Defined as } \\
\text { Those Receiving PELL } \\
\text { Within } 6 \text { Years of } \\
\text { Graduation) }\end{array}$ & $39.0 \%$ & $38.9 \%$ & $39.8 \%$ & $37.7 \%$ & $37.7 \%$ \\
\hline
\end{tabular}




\begin{tabular}{|c|c|c|c|c|c|}
\hline $\begin{array}{l}\text { 5G. Baccalaureate } \\
\text { Completion Without } \\
\text { Excess Credit Hours }\end{array}$ & 2004-2005 & 9 & 2006-2007 & 2007-2008 & 2008-2009 \\
\hline $\begin{array}{c}\% \% \text { of Total } \\
\text { Baccalaureate Degrees } \\
\text { Awarded Within } 110 \% \\
\text { of Hours Required for } \\
\text { Degree } \\
\end{array}$ & $54.3 \%$ & $53.7 \%$ & $51.7 \%$ & $39.1 \%$ & $39.8 \%$ \\
\hline $\begin{array}{l}\text { 5H. Undergraduate } \\
\text { Course Offerings }\end{array}$ & Fall 2004 & Fall 2005 & Fall 2006 & Fall 2007 & Fall 2008 \\
\hline $\begin{array}{c}\text { Number of } \\
\text { Undergraduate Course } \\
\text { Sections } \\
\end{array}$ & 2,861 & 3,050 & 3,118 & 3,275 & 3,023 \\
\hline $\begin{array}{c}\% \text { of Undergraduate } \\
\text { Course Sections With }< \\
30 \text { Students }\end{array}$ & $56.2 \%$ & $57.2 \%$ & $58.7 \%$ & $60.5 \%$ & $56.7 \%$ \\
\hline $\begin{array}{l}\% \text { of Undergraduate } \\
\text { Course Sections With } \\
>=30 \text { and }<50 \text { Students }\end{array}$ & $26.1 \%$ & $28.2 \%$ & $27.7 \%$ & $26.5 \%$ & $28.0 \%$ \\
\hline $\begin{array}{l}\% \text { of Undergraduate } \\
\text { Course Sections With } \\
>=50 \text { and }<100 \text { Students }\end{array}$ & $13.2 \%$ & $11.1 \%$ & $10.3 \%$ & $9.8 \%$ & $12.1 \%$ \\
\hline $\begin{array}{l}\% \text { of Undergraduate } \\
\text { Course Sections With } \\
>=100 \text { Students }\end{array}$ & $4.5 \%$ & $3.5 \%$ & $3.3 \%$ & $3.2 \%$ & $3.2 \%$ \\
\hline $\begin{array}{l}\text { 5I. Faculty Teaching } \\
\text { Undergraduates }\end{array}$ & 2004-2005 & 2005-2006 & 2006-2007 & 2007-2008 & 2008-2009 \\
\hline $\begin{array}{c}\text { Percentage of Credit } \\
\text { Hours Taught by } \\
\text { Faculty } \\
\end{array}$ & $59.6 \%$ & $60.5 \%$ & $60.4 \%$ & $61.4 \%$ & $62.5 \%$ \\
\hline $\begin{array}{c}\text { Percentage of Credit } \\
\text { Hours Taught by } \\
\text { Adjunct Faculty }\end{array}$ & $23.7 \%$ & $24.7 \%$ & $23.7 \%$ & $23.9 \%$ & $23.3 \%$ \\
\hline $\begin{array}{c}\text { Percentage of Credit } \\
\text { Hours Taught by } \\
\text { Graduate Students } \\
\end{array}$ & $16.2 \%$ & $14.4 \%$ & $15.5 \%$ & $14.2 \%$ & $13.8 \%$ \\
\hline $\begin{array}{l}\text { Percentage of Credit } \\
\text { Hours Taught by Other } \\
\text { Instructors }\end{array}$ & $0.5 \%$ & $0.4 \%$ & $0.4 \%$ & $0.4 \%$ & $0.4 \%$ \\
\hline
\end{tabular}




\section{6 - Graduate Education Data}

\begin{tabular}{|c|c|c|c|c|c|}
\hline $\begin{array}{l}\text { 6A. GraduateDegree Programs } \\
\text { Implemented or Terminated }\end{array}$ & & & & & \\
\hline Title and Program Level & $\begin{array}{c}\text { or } \\
\text { Termina- } \\
\text { tion? }\end{array}$ & $\begin{array}{l}\text { Approved by } \\
\text { UBOT }\end{array}$ & $\begin{array}{l}\text { Approved } \\
\text { by BOG, if } \\
\text { Needed }\end{array}$ & $\begin{array}{c}\text { tion Date, if } \\
\text { New }\end{array}$ & $\begin{array}{l}\text { Program } \\
\text { CIP Code }\end{array}$ \\
\hline Urban/Regional Planning - M & New & $5 / 31 / 2007$ & $\mathrm{n} / \mathrm{a}$ & Fall 2008 & 4.0301 \\
\hline Marketing -M & New & $5 / 31 / 2007$ & $\mathrm{n} / \mathrm{a}$ & Fall 2008 & 52.1401 \\
\hline Creative Writing - M & New & $9 / 6 / 2007$ & $\mathrm{n} / \mathrm{a}$ & Fall 2008 & 23.0501 \\
\hline Urban/Community Design - M & New & $1 / 24 / 2008$ & $\mathrm{n} / \mathrm{a}$ & Fall 2009 & 4.0401 \\
\hline Real Estate - M & $\mathrm{New}$ & $1 / 24 / 2008$ & $\mathrm{n} / \mathrm{a}$ & Fall 2009 & 52.1501 \\
\hline Materials Science/Engineering - M & New & $11 / 29 / 2007$ & $\mathrm{n} / \mathrm{a}$ & Fall 2008 & 14.0801 \\
\hline Journalism/Media Studies M & New & $11 / 29 / 2007$ & $\mathrm{n} / \mathrm{a}$ & Fall 2008 & 9.0401 \\
\hline History $-\mathrm{R}$ & New & $9 / 6 / 2007$ & $1 / 28 / 2009$ & Fall 2009 & 54.0101 \\
\hline Sociology - R & New & $9 / 6 / 2007$ & $1 / 28 / 2009$ & Fall 2009 & 45.1101 \\
\hline Government - R & New & $9 / 6 / 2007$ & $1 / 28 / 2009$ & Fall 2009 & 45.0901 \\
\hline Pharmacy - P & New & $6 / 12 / 2008$ & $1 / 28 / 2009$ & Fall 2010 & 51.2099 \\
\hline 6B. Graduate Degrees Awarded & $\begin{array}{l}2004- \\
2005\end{array}$ & 2005-2006 & 2006-2007 & $\begin{array}{l}2007- \\
2008\end{array}$ & $\begin{array}{l}2008- \\
2009\end{array}$ \\
\hline Master's and Specialist & 2,192 & 2,081 & 2,113 & 2,314 & 2,482 \\
\hline Research Doctoral (Total) & 194 & 184 & 223 & 229 & 248 \\
\hline Professional Doctoral (Total) & 103 & 93 & 122 & 143 & 154 \\
\hline Medicine & 103 & 93 & 116 & 115 & 114 \\
\hline Law & --- & --- & --- & --- & --- \\
\hline Pharmacy & --- & --- & --- & --- & --- \\
\hline \multirow{2}{*}{$\begin{array}{l}\text { 6C. Graduate Degrees Awarded in } \\
\text { Areas of Strategic Emphasis }\end{array}$} & \multicolumn{5}{|c|}{ Areas of Strategic Emphasis: Specific degree } \\
\hline & $\begin{array}{l}2004- \\
2005\end{array}$ & 2005-2006 & 2006-2007 & $\begin{array}{l}2007- \\
2008\end{array}$ & $\begin{array}{l}2008- \\
2009\end{array}$ \\
\hline Education & 158 & 170 & 193 & 194 & 222 \\
\hline $\begin{array}{l}\text { Health Professions } \\
\end{array}$ & 392 & 387 & 428 & 429 & 506 \\
\hline $\begin{array}{l}\text { Science, Technology, Engineering, } \\
\text { and Math }\end{array}$ & 488 & 429 & 454 & 544 & 530 \\
\hline Security \& Emergency Services & 15 & 33 & 6 & 36 & 53 \\
\hline Globalization & 41 & 37 & 42 & 46 & 41 \\
\hline Regional Workforce Needs & 488 & 441 & 431 & 482 & 517 \\
\hline $\begin{array}{c}\text { TOTAL: Areas of Strategic } \\
\text { Emphasis }\end{array}$ & 1582 & 1497 & 1554 & 1731 & 1869 \\
\hline 6D. Licensure Pass Rates & 2004 & 2005 & 2006 & 2007 & 2008 \\
\hline
\end{tabular}

Indicators for pass rates on other licensure exams will be added as data become 


\begin{tabular}{|c|c|c|c|c|c|}
\hline \multicolumn{6}{|c|}{7 - Research and Economic Development Data } \\
\hline $\begin{array}{l}\text { 7A. Research and Development } \\
\text { Expenditures }\end{array}$ & 2003-2004 & 2004-2005 & 2005-2006 & 2006-2007 & 2007-2008 \\
\hline $\begin{array}{c}\text { Federally Financed Academic } \\
\text { Research and Development } \\
\text { Expenditures (As Reported in } \\
\text { NSF Surveys) }\end{array}$ & $\$ 141,622$ & $\$ 143,051$ & $\$ 157,324$ & $\$ 171,272$ & $\$ 189,282$ \\
\hline $\begin{array}{l}\text { Total Academic Research and } \\
\text { Development Expenditures (As } \\
\text { Reported in NSF Surveys) }\end{array}$ & $\$ 273,424$ & $\$ 276,609$ & $\$ 304,804$ & $\$ 337,169$ & $\$ 342,665$ \\
\hline $\begin{array}{l}\text { Total Academic Research and } \\
\text { Development Expenditures Per } \\
\text { Full-Time, Tenured, Tenure- } \\
\text { Earning Faculty Member }\end{array}$ & $\$ 275,629$ & $\$ 238,662$ & $\$ 253,159$ & $\$ 278,652$ & $\$ 291,630$ \\
\hline $\begin{array}{c}\text { 7B. Other Research and } \\
\text { Economic Development } \\
\text { Outcomes [for Entire } \\
\text { University]* }\end{array}$ & 2003-2004 & 2004-2005 & 2005-2006 & 2006-2007 & 2007-2008 \\
\hline Invention Disclosures Received & 138 & $\mathrm{~N} / \mathrm{A}$ & 109 & 110 & 139 \\
\hline Total U.S. Patents Issued & 22 & 23 & 29 & 31 & 31 \\
\hline $\begin{array}{c}\text { Patents Issued Per 1,000 Full- } \\
\text { Time, Tenure and Tenure- } \\
\text { Earning Faculty }\end{array}$ & 22 & 20 & 24 & 26 & 26.4 \\
\hline $\begin{array}{c}\text { Total Number of } \\
\text { Licenses/Options Executed }\end{array}$ & 11 & 20 & 21 & 23 & $28 \mathrm{e}$ \\
\hline $\begin{array}{c}\text { Total Licensing Income } \\
\text { Received }\end{array}$ & $\$ 1,357,725$ & $\$ 1,548,818$ & $\$ 1,704,025$ & $\$ 2,099,712$ & $\$ 1,831,000$ \\
\hline $\begin{array}{c}\text { Jobs Created By Start-Ups in } \\
\text { Florida }\end{array}$ & Data colle & tion metho & $\begin{array}{l}\text { lology still } \\
\text { endnote.) }\end{array}$ & nder discu & ion. (See \\
\hline
\end{tabular}




\begin{tabular}{|c|c|c|}
\hline $\begin{array}{l}\text { Name of Center of Excellence: } \\
\text { Center of Excellence for Biomolecular Identification and Targeted } \\
\text { Therapeutics (FCoE-BITT) }\end{array}$ & $\begin{array}{c}\text { From First } \\
\text { Year Up To } \\
\text { Most } \\
\text { Recent } \\
\text { Year }\end{array}$ & $\begin{array}{l}\text { Most } \\
\text { Recent } \\
\text { Year }\end{array}$ \\
\hline \multicolumn{3}{|l|}{ Research Effectiveness } \\
\hline Competitive Grants Applied For and Received & $\begin{array}{c}\text { Received: } \\
\$ 48,877,702\end{array}$ & $\begin{array}{c}\text { Received: } \\
\$ 14,982,803\end{array}$ \\
\hline Total Research Expenditures & $\$ 33,610,666$ & $\$ 16,621,976$ \\
\hline Publications in Refereed Journals From Center Research & 57 & 27 \\
\hline Professional Presentations Made on Center Research & 80 & 50 \\
\hline Invention Disclosures Filed and Issued & 10 & 10 \\
\hline Technologies Licensed and Revenues Received & \begin{tabular}{|c} 
Center Co- \\
PIs: 2 licensed \\
technologies \\
Center Co- \\
PIs: $\$ 160,071$ \\
in licensed \\
Revenue
\end{tabular} & 1 \\
\hline
\end{tabular}




\begin{tabular}{|c|c|c|}
\hline Collaboration Effectiveness & & \\
\hline Collaborations with Other Postsecondary Institutions & \begin{tabular}{|c|}
17 \\
Community \\
colleges, \\
Univ. PA, UF, \\
UNF, UWF, \\
Western \\
Carolina \\
Univ., Wayne \\
State Univ., \\
Karmonos \\
Cancer \\
Center, \\
Portland State \\
Univ., Univ. \\
of Paris, Univ. \\
of Oviedo \\
(Spain), Univ. \\
of Shiraz \\
(Iran) \\
\end{tabular} & $\begin{array}{c}17 \\
\text { Community } \\
\text { colleges, } \\
\text { Univ. PA, } \\
\text { UF, UNF, } \\
\text { UWF, } \\
\text { Western } \\
\text { Carolina } \\
\text { Univ., } \\
\text { Wayne State } \\
\text { Univ., } \\
\text { Karmonos } \\
\text { Cancer } \\
\text { Center, } \\
\text { Portland } \\
\text { State Univ., } \\
\text { Univ. of } \\
\text { Paris, Univ. } \\
\text { of Oviedo }\end{array}$ \\
\hline Collaborations with K-12 Education Systems/Schools & \begin{tabular}{|l|}
4 \\
\end{tabular} & 4 \\
\hline Collaborations with Private Industry & 12 & 10 \\
\hline Students Supported with Center Funds & 45 & 8 \\
\hline Students Graduated & 0 & 3 \\
\hline Job Placements of Graduates Upon Leaving the Center & 0 & $\begin{array}{c}\text { 3: Ross } \\
\text { University } \\
\text { Medical } \\
\text { School - } \\
\text { Medical } \\
\text { Student; UT } \\
\text { Southwester } \\
\text { n Medical } \\
\text { Center - } \\
\text { Postdoctoral } \\
\text { Studies; USF } \\
\text { College of } \\
\text { Medicine - } \\
\text { Postdoctoral } \\
\text { Studies. }\end{array}$ \\
\hline
\end{tabular}




\begin{tabular}{|c|c|c|}
\hline Economic Development Effectiveness & & \\
\hline Business Start-Ups in Florida & 0 & 5 \\
\hline Jobs Created and Jobs Saved in Florida & \begin{tabular}{|c} 
Center: 7 jobs; \\
Draper \\
Laboratory: \\
165 jobs \\
(average \\
wage: \\
$\$ 75,000)$ as its \\
facilities are \\
established; \\
Molecular \\
and Specialty \\
Diagnostics \\
Center \\
(MSDC): 20 \\
jobs as its \\
facilities are \\
established
\end{tabular} & $\begin{array}{l}\text { Center: } 7 \\
\text { jobs: Draper } \\
\text { Laboratory: } \\
\text { Collaborative } \\
\text { positions } \\
\text { need more } \\
\text { time to } \\
\text { determine } \\
\text { the count. }\end{array}$ \\
\hline Specialized Industry Training and Education & \begin{tabular}{|c|} 
Florida \\
Advanced \\
Technological \\
Education \\
Center and \\
COE are \\
assessing \\
biotech \\
workforce \\
capability and \\
capacity and \\
establishing \\
partnership \\
relationships \\
among NSF \\
Biotech \\
Centers of \\
Excellence to \\
develop \\
curricula to \\
match \\
industry \\
employee \\
requirements.
\end{tabular} & \begin{tabular}{|c} 
Florida \\
Advanced \\
Technologica \\
1 Education \\
Center and \\
COE are \\
assessing \\
biotech \\
workforce \\
capability \\
and capacity \\
and \\
establishing \\
partnership \\
relationships \\
among NSF \\
Biotech \\
Centers of \\
Excellence to \\
develop \\
curricula to \\
match \\
industry \\
employee \\
requirements
\end{tabular} \\
\hline Dollars Acquired from Venture Capitalists and Other Investments & 0 & 0 \\
\hline
\end{tabular}


Narrative Comments [Most Recent Year]

Move promising biotechnology products to market and commercialization in Florida

To date, FCoE-BITT Members have 19 invention disclosures that have been filed and issued. Two of these technologies have been licensed, generating a total of $\$ 160,071$ in licensing revenues. A spin-off company has been created by BITT co-PI Ed Turos, Nanopharma Technologies, Inc. Nanopharma is located in the USF incubator, and focuses its primary efforts on the further development of patented new drugs from university labs in the area of infectious disease treatment. At the Center, FCoE-BITT Members are developing a variety of products that are used to detect, diagnose or treat illness. Some examples include drugs against malaria, E. coli O157:H7, anthrax and cancer; detection devices to monitor our food and water for bacteria; and therapeutic devices that can deliver treatment for melanoma.

Create jobs in the biotechnology industry in the State of Florida and Tampa Bay region

The Center directly employs 14 people, including administrative staff, scientists and laboratory support staff. Additional jobs are created through external funding secured by our membership as a result of FCoE-BITT Programs and Resources such as our Core Facilities. The level of external funding secured by our membership to date totals $\$ 63,860,505$. Further study is required to determine what portion of that funding can be attributed to FCoE-BITT activities and how many jobs have been created from the funding. Other collaborations supporting local businesses, such as Draper Laboratories, Nanopharma and Innovative Quality Sciences, Inc, certainly contribute to the generation of jobs in those organizations.

Provide workforce development through universities and colleges to foster and support the biotechnology industry in the State of Florida

Through our partnership with the Florida Advanced Technological Education Center (FLATE), FCoE-BITT has developed and implemented a short screening survey tool to assess the current biotechnology-based workforce strengths and needs. A more detailed follow up is planned to establish a baseline for subsequent determination of skill gaps for the biotechnology workforce within the Tampa Bay region (Hillsborough, Pinellas, Polk, Pasco, Sarasota, Manatee and Hernando counties). A report for the first phase of the study is available through our FCoE BITT office at Hillsborough Community College. Subsequent phases of these survey studies will focus on biotechnology research and development companies as well as major healthcare facilities that would be candidate users of FCoE-BITT's detection, diagnostic and therapeutic technologies. The results of these surveys will be used to tailor course content or direct training at USF and in the local community colleges.

Insert additional pages, as needed for additional Centers. 


\section{Narrative Comments [Most Recent Year]}

(Limit to a maximum of $1 / 2$ page per grant.)

USF Phase I: Early Stage RAID $(\$ 50,000)$ A no cost extension was received for this project.

Program Setup and Selection: Initial review of the USF portfolio was conducted to develop a short list of technologies to evaluate for inclusion in the program. The list was narrowed to 5 potential technologies.

Interviews were conducted with faculty to discuss interest in participation, additional scientific considerations, and the process moving forward if their technology is selected.

Subcontractor Evaluation and Selection: Several potential contractors for training and development of the RAID applications were contacted by phone, email, and in person. The contractors experience and expertise were evaluated. Process, cost, and scope of the project were discussed. At least two applications should be possible based on initial discussions if USF is actively involved in the process and dedicates a graduate student in the faculty lab who worked on the project and internal staff to work closely with external contractors. The contractor was narrowed to SRI. Terms for the engagement were negotiated and agreed to. Two technologies were selected and initial efforts begun to submit one application by the August Deadline for cancer therapeutic compounds. Initial drafting for the next deadline has been started on the second application. Optimistic that there is a possibility of more than two applications as a result of this important grant.

USF Phase II: Platinum Compounds $(\$ 50,000)$

Matching Funds and Compound Synthesis: Contract is in place with external university to synthesize the primary compounds and matching funds are being expended. A no cost extension was granted on the research contract. The first and second scientific reports were received under the matching funds grant. Satisfactory quantity and quality of compounds has not yet been achieved for the next level of studies required. Additional interaction with former USF faculty members and contract scientists ongoing. We remain optimistic that there will be a positive result from the synthesis experiments. Upon completion of synthesis, business plan will be initiated.

Additional grant programs with commercialization focus:

USF has provided a number of matching grants to many top high-tech businesses through the Florida High

Tech Corridor Council's Matching Grants Research Program. Since FY 04-05, USF has awarded more than \$ 21.3 million in grant funding to assist over 76 Florida-based companies' conduct research by leveraging the expertise of the University in their applied research projects. A number of the successful projects have produced marketed products, in a variety of fields, from personal hygiene to wireless communications. 
8 - Voluntary Support of Higher Education*

\begin{tabular}{|c|c|c|c|c|c|c|}
\hline $\begin{array}{c}\text { Endowment } \\
\begin{array}{c}\text { Market Value (in } \\
\text { 2009 Dollars) }\end{array}\end{array}$ & $2003-2004$ & $2004-2005$ & $2005-2006$ & $2006-2007$ & $2007-2008$ & $2008-2009$ \\
\hline $\begin{array}{c}\text { Annual Gifts } \\
\text { Received } \\
\text { (\$ Amount) }\end{array}$ & $\$ 34,044,392$ & $\$ 22,733,927$ & $\$ 46,346,593$ & $\$ 56,826,407$ & $\$ 44,682,695$ & $\$ 34,010,969$ \\
\hline $\begin{array}{c}\text { Percentage of } \\
\text { Graduates Who } \\
\text { Are Alumni }\end{array}$ & $6.0 \%$ & $5.9 \%$ & $5.6 \%$ & $4.8 \%$ & $8.2 \%$ & $8.0 \%$ \\
\hline \\
* Data will be provided by Board staff for institutions that have reported said data \\
through the NACUBO Endowment Study and the CAE Voluntary Support of Education \\
(VSE) Survey.
\end{tabular}

\section{[INCLUDE ADDITIONAL BACKGROUND DATA ASSOCIATED WITH GRAPHS INCLUDED FOR GOAL \#4.]}

\section{ENDNOTES:}

- Currently, teacher certification examination pass rates are reported for program completers only, resulting in a $\mathbf{1 0 0} \%$ pass rate (because state-approved programs require passage of the certification exams for completion). Engineering, accounting, architecture, and other professional licensure data, gathered by the respective licensing boards and housed within the Department of Business and Professional Regulation, are not currently formatted and do not contain sufficient information to match to SUS data. Such a match is necessary to develop metrics reflecting pass rates for graduates in those fields. Board of Governors staff will work with individuals from the appropriate agencies to try to get data in the needed format.

- Board staff are continuing to work with the SUS Technology Transfer Directors to determine the best way to capture consistent information regarding Jobs Created By Start-Ups in Florida in a cost-effective manner.

\section{[Additional definition information will be added to final document.]}




\section{Progress on Other Primary Institutional Goals and Metrics As Outlined in}

the University Work Plan

$P$ rovide a report on progress to date on three - five other primary university goals and metrics that were identified in the institution's last annual work plan/proposal.

[NOTE: In 2009, universities may only be able to identify goals and metrics or report on progress on institutional strategic planning goals already in place.] 